\title{
Confined Employment: Exploring Labor Marginalization in Workplace Safety
}

\author{
Palvasha Shahab
}

\begin{abstract}
This chapter argues that Pakistan has never had a bona fide system of occupational safety and health (OSH) laws, policies, standards or enforcement mechanisms ("OSH infrastructure"). Instead, the country's present OSH infrastructure remains divorced from workers' most urgent needs and the country's institutional capacity - effectively leaving workers without protection. This chapter traces the progress of the fire, delineates violations of OSH law and provides an account of the actions and inactions of various actors involved. In doing so, it highlights the gap between the OSH system's deficiencies and the fatalities they caused; outlining what measures were legally required to prevent such a tragedy but they were not in place. Then, it explores the geneology of these illegalities and accompanying apathies as it traces the history of Pakistan's OSH infrastructure back to its origins under British colonial rule and contextualises it with the overarching global (politico-economic) order in which the factory fire should perhaps be seen. Thus, it renders visible the historical trajectories and contemporary political and economic factors that have led to workers' persistent exclusion from the politico-legal sphere, denial of their rights and their dehumanisation-specifically in Pakistan and generally in the Global South. It concludes by identifying some directions that could be taken for a renewed and vitalised mandate to govern the $\mathrm{OSH}$ infrastructure in Pakistan.
\end{abstract}

Keywords Occupational health and safety $\cdot$ Labour $\cdot$ Global South $\cdot$ Modern slavery $\cdot$ Colonialism $\cdot$ Imperialism $\cdot$ Pakistan $\cdot$ Factory fire

I would like to express deep appreciation for the thoughtful and acutely constructive feedback provided by Faisal Siddiqi, Miriam Saage-Maaß, Michael Bader and Daniyal Ahmed. I would also like to thank Allison West for her work.

\footnotetext{
P. Shahab $(\bowtie)$

Rasheed Razvi Centre for Constitutional and Human Rights (RCCHR), Karachi, Pakistan

Legal Aid Foundation for Victims of Rape and Sexual Assault (LAFRSA), Karachi, Pakistan e-mail: palvasha.shahab@columbia.edu
} 


\section{Introduction}

The 2012 Ali Enterprises factory fire near the Baldia Town area of Karachi, Pakistan, left many orphans, parents, widows, and widowers traumatised. It also left many of them destitute, without their family's main breadwinner. What came to be known as the Baldia factory fire was perhaps the goriest industrial accident in Pakistani history, taking at least 258 lives and injuring 55 others. ${ }^{1}$ Following the fire, chaos ensued. Many bodies were burnt beyond recognition and several corpses had melted into each other so indiscernibly that it took the investigation agencies almost a year to identify the victims through DNA tests. In several instances, graves were exhumed to correctly establish who had been laid to rest. The high death toll was due to the factory's lack of adequate health and safety infrastructure. Only two thirds of those present in the building on the day of the fire had been able to escape. ${ }^{2}$

The Ali Enterprises (AE) factory produced garments for export; around 70 percent of the production was for the German company, KiK Textilien und Non-Food $\mathrm{GmbH}(\mathrm{KiK}){ }^{3}$ The AE factory was situated in the Sindh Industrial Trading Estate $(\mathrm{SITE})^{4}$ near the Baldia Town area of Karachi and was owned and operated by a local business family, by the name of Bhailas. ${ }^{5}$ With regard to workplace safety standards, three different authorities had jurisdiction over the factory: the Sindh Building Control Authority (SBCA), the SITE Management, and the Labour and Human Resources Department of Sindh (Sindh Labour Department). Yet, none of them had ever inspected the factory building, either before or after its occupation. ${ }^{6} \mathrm{~A}$ staggering 90 percent of the workers employed at the factory were not registered with the Sindh Employees Social Security Institution (SESSI) or any other

\footnotetext{
${ }^{1}$ Report of the Judicial Commission on the Baldia Factory Fire incident, Karachi, 28 August 2013, Court File of Constitutional Petition No. 3318 of 2012, p. 1379.

${ }^{2}$ Forensic Architecture, The Ali Enterprises Factory Fire, 30 January 2018, www.forensicarchitecture.org/investigation/the-ali-enterprises-factory-fire (last accessed 15 August 2020).

${ }^{3} \mathrm{KiK}$ : Paying the Price for Clothing Production in South Asia/Pakistan Factory Fire Victims Sue German Retailer KiK. ECCHR, www.ecchr.eu/en/case/kik-paying-the-price-for-clothing-produc tion-in-south-asia/ (last accessed 15 August 2020).

${ }^{4}$ SITE was established the very year that Pakistan gained independence, in 1947, as part of efforts to put Pakistan on track for industrialisation. Today, it is the largest industrial trading estate in Asia. www.site.com.pk/wordpress/?page_id=1433 (last accessed 14 August 2020).

${ }^{5}$ Gayer (2019).

${ }^{6}$ At the time of the fire, the Factories Act 1934, prescribed the basic minimum safety standards and stipulated that there be inspectors in every district. However, across the board, inspections have remained haphazard and were often avoided entirely, either as a matter of policy or because there were not enough inspectors, or because factories were simply not registered with the Directorate of Labour or had not notified the Chief Inspectors of their operations as per Section 10 of the Factories Act 1934. For a detailed discussion, please see Sect. 2 of this chapter.
} 
institution like the Workers Welfare Fund (WWF) or the Employees Old-Age Benefits Institution (EOBI). ${ }^{7}$

In the aftermath of the disaster, from 2012 to 2019, lawyer Faisal Siddiqi and his team tirelessly litigated the matter in Pakistan, in the interest of the survivors and the heirs of the deceased, through two separate constitutional petitions before the High Court of Sindh, and the accompanying criminal cases. ${ }^{8}$ The European Center for Constitutional and Human Rights also litigated the matter in Germany, filing a lawsuit in the Dortmund Regional Court. ${ }^{9}$ Various national and international actors, including but not limited to, the Pakistan Institute for Labour Education and Research (PILER), the National Trade Union Federation (NTUF), the Clean Clothes Campaign and ECCHR, have steadfastly continued to lobby for the survivors and the heirs of the deceased to be compensated, and for measures to ensure safer workplaces in the future. ${ }^{10}$ The lawyers, activists, and advocacy experts from these groups have also worked together with the Ali Enterprises Factory Fire Affectees Association (AEFFAA) since its formation. Following negotiations facilitated by the International Labour Organization (ILO), the families of the deceased or permanently injured were awarded lifelong pensions and a compensation whose total amount was unprecedented in Pakistan. ${ }^{11}$

\subsection{The Task Ahead}

This chapter will show that Pakistan has never had a bona fide system of occupational safety and health (OSH) laws, policies, standards or enforcement mechanisms ("OSH infrastructure"). Instead, the country's present OSH infrastructure both lacks the resources and the political will that is needed to enforce it and remains divorced from workers' most urgent needs, effectively leaving them without protection. The chapter begins by identifying all of the actors who either took action or were supposed to take action; to prevent fatalities in the AE factory fire, and in its

\footnotetext{
${ }^{7}$ Enquiry Report: Fire Incident at Ali Enterprises S.I.T.E Karachi on 11th September 2012. Federal Investigation Agency, Sindh Zone Karachi, 3 October 2012, Court File of Constitutional Petition No. 3318 of 2012, pp. 1291-1333.

${ }^{8}$ Baldia Factory Fire Case Litigation. RCCHR, www.rcchr.com.pk/practice/baldia-factory-firecase-litigation/ (last accessed 15 July 2020); However, when the criminal case was (controversially) taken into the jurisdiction of the Anti-Terrorism Courts, the court rejected Faisal Siddiqi's application to be allowed to be a party to the proceedings on behalf of the victims.

${ }^{9}$ Kik Lawsuit (Re Pakistan), Business and Human Rights Resource Centre, 7 October 2015, www. business-humanrights.org/en/kik-lawsuit-re-pakistan (last accessed 15 July 2020).

${ }^{10}$ Landmark compensation arrangement reached on 4th anniversary of deadly Pakistan factory fire. IndustriALL, 10 September 2016, www.industriall-union.org/landmark-compensation-arrange ment-reached-on-4th-anniversary-of-deadly-pakistan-factory-fire (last accessed 15 July 2020).

${ }^{11}$ ILO, Victims of 2012 Ali Enterprises factory fire receive additional compensation, 20 May 2018, www.ilo.org/global/about-the-ilo/newsroom/news/WCMS_629839/lang\%2D\%2Den/index.htm (last accessed 14 July 2020).
} 
aftermath. It then re-traces the progression of the fire whilst simultaneously identifying the legal violations involved. In doing so, it will highlight the gap between the $\mathrm{OSH}$ infrastructure and its enforcement that resulted in the fatalities of the $\mathrm{AE}$ factory fire, outlining shortcomings and what would have been required to prevent such a tragedy. After this, it traces the history of Pakistan's OSH infrastructure back to its origin under British colonial rule, and this is followed by an attempt at contextualising the larger global economic and political situation, in which the $\mathrm{AE}$ factory fire should be seen. It thus renders visible the historical trajectories and political and economic factors that have led to workers' persistent exclusion from politico-legal rights in Pakistan, more broadly the Global South (noting that these exclusionary trends are spreading fast to the Global North). It concludes by offering some directions through which the OSH infrastructure in Pakistan can be revitalised.

The chapter also shows how important it is to understand that OSH infrastructures are not static nor are they universal normative edicts that are either applied and enforced; or not. The Pakistani case reveals a rather messy reality in which OSH infrastructure was morphed and applied under colonial rule and later revoked under trade liberalisation, according to the contemporary trade priorities, and according to global demands. In light of this, I argue that the existing OSH infrastructure in Pakistan and the (global) mass contractualisation of labour that has accompanied its development have dehumanised and zombified workers. The workers have become the homo sacer, incarcerated in the state of exception, unable to access legal protection and stuck in the limbo between recognised (factual) workers and non-recognised (non-legal) workers; as they are employed through subcontractors, and because they are not in a direct employment relationship with the (local and foreign) employers who profit from their labour and who are or should be responsible for their safety. These workers are unprotected by the legal provisions designed to protect them. Workers provide labour in practice, while labour and safety laws provide protection in theory-the two do not meet to create a politically and legally empowered worker who can demand safe working conditions.

This chapter argues that the distances created by the large-scale outsourcing of production labour - by transnational corporations - and by the factories' or production units' hiring of workers through various subcontractors, all enable the evasion of responsibility for occupational health and safety. National labour laws do not apply to transnational corporations-these transnational corporations go wholly unregulated. They are able to generate vast profits from the labour of workers who are labouring in factories to whom the transnational corporations have outsourced their production work; without having to bear any responsibilities for the workers' safety or other rights. ${ }^{12}$ These distances also render inaudible any and all employment and safety-related concerns of the workers. Indeed, the economic and political factors that predetermine OSH failures penetrate so deeply that they cannot be undone with the snap of two fingers. I argue that even if it musters the political will to protect its workers, Pakistan's government cannot simply copy and paste OSH infrastructures from the Global North or hold them up as the invariable

\footnotetext{
${ }^{12}$ Mende (2020).
} 
universal standard because it does not have the same political autonomy nor the same conditions as the nations in the Global North. OSH must be reimagined in Pakistan (and other similarly placed countries in the Global South) to balance worker safety with the global and local, economic and political, realities that confront and shape it. Moreover, self-regulation by businesses and contract-based OSH solutions are also not a sustainable answer because, as we will shortly see, they are either purely cosmetic or too flimsy to last. Truly workable OSH solutions must incorporate workers' inputs, reflect institutional capacities, and be economically and politically viable. We need workable and effective OSH infrastructure based on realities on the ground, not on colonial or globally ordained standards.

\subsection{Homo sacer: Workers in South Asian Textile Industries}

At the time of the fire, many of the doors in the AE factory had been permanently locked from the outside, by the factory management, while the fire's heat rendered other doors inoperable. As a result, there was only one door through which all of the workers present in the factory that day could escape at all. ${ }^{13}$ Across both time and geography, factory owners have engaged in the illegal practice of locking doors from the outside whenever and wherever it has been possible to get away with it. The alleged purpose of this practice is to prevent workers from taking extra breaks and stealing merchandise. ${ }^{14}$ Workers were locked inside during the 1911 Triangle Shirtwaist Factory fire in New York, ${ }^{15}$ the 1991 Hamlet Chicken processing plant fire in North Carolina, ${ }^{16}$ the 1993 Kader Toy Factory fire in Thailand, ${ }^{17}$ and the 2012 Tazreen Fashions factory fire in Dhaka. ${ }^{18}$ Like the Tazreen Fashions fire, ${ }^{19}$ the Ali Enterprises fire was further aggravated by negligently stored bales of cloth, which also blocked other possible exits and further trapped workers inside. ${ }^{20}$

\footnotetext{
${ }^{13}$ Clean Clothes Campaign, The Timeline of the Ali Enterprises Case, www.cleanclothes.org (last accessed 12 August 2020).

${ }^{14}$ Orleck (2018), p. 100.

${ }^{15}$ The Triangle Shirtwaist Factory Fire. Occupational Safety and Health Administration, 2011, www.osha.gov/aboutosha/40-years/trianglefactoryfire (last accessed 2 August 2020).

${ }^{16}$ See Diamond A, The Deadly 1991 Hamlet Fire Exposed the High Cost of "Cheap". Smithsonian Magazine, 8 September 2017, www.smithsonianmag.com/history/deadly-1991-hamlet-fireexposed-high-cost-cheap-180964816/ (last accessed 30 July 2020); Taylor P, 25 die as fire hits N.C. poultry plant. Washington Post, 4 September 1991, www.washingtonpost.com/archive/ politics/1991/09/04/25-die-as-fire-hits-nc-poultry-plant/0fdce6ba-a8e2-46a0-8c48-806012a98938/ (last accessed 30 July 2020).

${ }^{17}$ Thai Factory Fire's 200 Victims Were Locked Inside, Guards Say. New York Times, 12 May 1993, www.nytimes.com/1993/05/12/world/thai-factory-fire-s-200-victims-were-locked-insideguards-say.html (last accessed 30 July 2020).

${ }^{18}$ The Tazreen Factory Fire occurred on 24 November 2012. Orleck (2018), p. 136.

${ }^{19}$ Orleck (2018), p. 137.

${ }^{20}$ Enquiry Report: Fire Incident at Ali Enterprises S.I.T.E Karachi on 11th September 2012. Federal Investigation Agency, Sindh Zone Karachi, 3 October 2012, Court File of Constitutional Petition
} 
Thus, the AE factory was not uniquely dangerous, but it was fatally dangerous. To this day, workers in Pakistan are commonly employed in buildings on the verge of similar disasters, where their safety hangs precariously in the balance. ${ }^{21}$ Prison-like conditions also remain common in Pakistani factories, particularly in the textile and garment industry. ${ }^{22}$ Laws against unsafe working conditions exist, but they have negligible effect on workers' lived realities, and evidently do not protect them from death at the workplace. ${ }^{23}$ I argue that the workers forced to abide by these dangerous conditions are the living dead-the zombified homo sacer. The homo sacer is understood here as the "the accursed individual"; such a person has been made invisible to the law and has, therefore, lost the rights that were guaranteed to them by virtue of their human-ness; "reduced to the non-human. Denied rights, this person becomes the non-entity." ${ }^{24}$ For the homo sacer, there is no rule of law; captive outside the kingdom of law, the homo sacer is governed only by the needs of the Sovereign. ${ }^{25}$

Through the AE factory fire, many stakeholders, activists and citizens, both in Pakistan and beyond, were shaken out of either ignorance-or perhaps a numbness or resignation that comes from the routinisation of risk. In one sense, the AE factory fire was a rupture. ${ }^{26}$ It was a tragedy so big and horrifying that it could not be ignored. The rupture was followed by a degree of momentum for change. It was almost as if in their deaths and injuries the workers had emitted a rallying scream, desperate for the world to pay attention to the sub-human conditions in which they,

No. 3318 of 2012, p. 1313; Forensic Architecture, The Ali Enterprises Factory Fire, 30 January 2018, forensic-architecture.org/investigation/the-ali-enterprises-factory-fire (last accessed 15 August 2020).

${ }^{21} \mathrm{Six}$ years after Baldia factory fire, working conditions still not changed. Express Tribune, 10 September 2018, www.tribune.com.pk/story/1799215/1-six-years-baldia-factory-fire-workingconditions-still-not-changed/ (last accessed 12 August 2020).

${ }^{22} \mathrm{Six}$ years after Baldia factory fire, working conditions still not changed. Express Tribune, 10 September 2018, www.tribune.com.pk/story/1799215/1-six-years-baldia-factory-fire-workingconditions-still-not-changed/ (last accessed 12 August 2020).

${ }^{23}$ Ijaz S, No Room to Bargain. Human Rights Watch, 23 January 2019, www.hrw.org/report/2019/ 01/23/no-room-bargain/unfair-and-abusive-labor-practices-pakistan (last accessed 12 August 2020).

${ }^{24}$ Nashef (2017), p. 147; Agamben (1998), p. 86.

${ }^{25}$ For a discussion on the nature and character of the sovereign, see Mbembe (2003) and Elshtain (1991), pp. 1355-1378.

${ }^{26}$ To briefly shed light on what is meant by this, the following quote might be useful: "[R]eality is grounded on a 'void' of 'inconsistent multiplicity', which is at once void and excess. Normally, the state, the count-for-one and the dominant ideology cover up this foundation. But it remains present - imprisoned or kettled, so to speak, at the site of the excluded part. An Event happens when the excluded part appears on the social scene, suddenly and drastically. It ruptures the appearance of normality and opens a space to rethink reality from the standpoint of its real basis in inconsistent multiplicity." McLaverty-Robinson A, An A to Z of Theory. Ceasefire Magazine, 15 December 2014, www.ceasefiremagazine.co.uk/alain-badiou-event/ (last accessed 12 August 2020). 
and their counterparts, were and are forced to work, day in and day out. ${ }^{27}$ The AE factory fire demanded change in workplace safety in Pakistan, but real change has still yet to come.

Similar working conditions to those in Pakistan also prevail in other parts of the world-predominantly, in the Global South. ${ }^{28}$ Across these different locales, a globalised OSH discourse bridges discussions on workplace safety, including building and fire safety. ${ }^{29}$ Existing at the intersection of labour law and policy, OSH incorporates aspects of employment law (dangerous buildings, sexual harassment, and mentally or physically abusive environments), health (occupational diseases particular to certain jobs, mental health issues, and the safety of healthcare professionals), building regulation (building approvals and inspections), engineering (building safety), urban planning (zoning considerations such as not placing schools or hospitals near factories), rural development (farming, mining or fishing related accidents and disease control), and even chemistry (effective disposal of chemical waste and hazardous substances) and geology (safe and sustainable mining or agricultural practices). According to statistics from 2003, the ILO/WHO Joint Committee on Occupational Health, estimated that there are between 1.9 to 2.3 million work-related fatalities in the world every year, of which around 355,000 are workplace accidents. The committee also estimates that the cost of all work-related accidents and diseases amounts to about four percent of the world's Gross National Product. ${ }^{30}$

\section{A Fire Raging Through Missed Chances: The Persisting Disjunct Between Practical Reality and Legal Fiction}

If the laws regarding building and fire safety in force at the time of the Ali Enterprises fire had been abided by and enforced at the factory, it is likely that not a single worker would have died. ${ }^{31}$ This section analyses the spread of the fire with respect to the existing laws that were being violated at the factory at the time.

\footnotetext{
${ }^{27}$ Labour safety remains lax seven years after Baldia factory fire. Express Tribune, 12 September 2019, www.tribune.com.pk/story/2054356/1-labour-safety-remains-lax-seven-years-baldia-fac tory-fire/ (last accessed 12 August 2020); Ashraf Z, Fire breaks out at Gadani shipbreaking yard. Express Tribune, 22 December 2016, www.tribune.com.pk/story/1271626/fire-breaks-gadanishipbreaking-yard/ (last accessed 3 August 2020); Ali I, Six workers fall to death after Construction lift buckles in Clifton. Daily Dawn, 10 March 2019, www.dawn.com/news/1468611 (last accessed 4 August 2020).

${ }^{28}$ Powell (2014), pp. 109-122.

${ }^{29}$ See Occupational Health. www.who.int/health-topics/occupational-health (last accessed 2 August 2020).

${ }^{30}$ Report of the Thirteenth Session of the Joint ILO/WHO Committee on Occupational Health, JCOH/2003/D.4 (2003), p. 3, www.ilo.org/wcmsp5/groups/public/\%2D\%2D-ed_protect/\%2D\% 2D-protrav/\%2D\%2D-safework/documents/publication/wcms_110478.pdf (last accessed 2 August 2020).

${ }^{31}$ Forensic Architecture, The Ali Enterprises Factory Fire, 30 January 2018, www.forensicarchitecture.org/investigation/the-ali-enterprises-factory-fire (last accessed 15 August 2020).
} 


\subsection{Legislative and Factual Background of the Ali Enterprises Factory Fire}

In 2012, at the time of the fire, OSH in the Pakistan's Sindh province, where the AE factory fire occurred, was regulated by the Factories Act 1934, the Sindh Factories Rules (1975), and the Sindh Labour Department was responsible for ensuring their implementation. The Ali Enterprises factory was situated in Karachi, where the Sindh Building Control Ordinance (SBCO) 1979, and the Karachi Building and Town Planning Regulations (KBTPR) 2002, governed building safety. The statutory body responsible, for their implementation, is the Sindh Building Control Authority (SBCA). As this chapter traces the progress of the fire and simultaneously identifies relevant $\mathrm{OSH}$ violations at the factory, it primarily relies on factual evidence from the report prepared by Pakistan's Federal Investigation Agency (FIA Report), based on the investigation conducted immediately after the fire, which was also submitted before the High Court of Sindh. ${ }^{32}$ As a secondary source of factual evidence, it also draws on the Forensic Architecture analysis of the Ali Enterprises factory fire which provides an eye-opening visual aid for reconstructing the fire and was submitted before the Regional Court in Dortmund, Germany, on behalf of ECCHR. ${ }^{33}$

According to the FIA Report, the building that caught fire was Block-A of the Ali Enterprises factory. It covered over 1600 square metres and had five levels: a basement, a ground floor, a mezzanine floor, a first floor and a second floor. ${ }^{34}$ The fire started at roughly $6: 30 \mathrm{pm}^{35}$ on 11 September 2012 , and raged until 2:30 pm the next day. ${ }^{36}$ The first fire engine reached the factory at approximately 7:00 pm, about half an hour after the fire started, but reinforcements had to be called soon after. ${ }^{37}$ According to the Forensic Architecture analysis, there should have been no more than 268 (plus or minus 40) persons present in the building at any given time.

\footnotetext{
${ }^{32}$ Enquiry Report: Fire Incident at Ali Enterprises S.I.T.E Karachi on 11th September 2012. Federal Investigation Agency, Sindh Zone Karachi, 3 October 2012, Court File of Constitutional Petition No. 3318 of 2012, pp. 1291-1355.

${ }^{33}$ Forensic Architecture, The Ali Enterprises Factory Fire, 30 January 2018, www.forensicarchitecture.org/investigation/the-ali-enterprises-factory-fire (last accessed 15 August 2020).

${ }^{34}$ Enquiry Report: Fire Incident at Ali Enterprises S.I.T.E Karachi on 11th September 2012. Federal Investigation Agency, Sindh Zone Karachi, 3 October 2012, Court File of Constitutional Petition No. 3318 of 2012, p. 1301; Forensic Architecture, The Ali Enterprises Factory Fire, 30 January 2018, www.forensic-architecture.org/investigation/the-ali-enterprises-factory-fire (last accessed 15 August 2020).

${ }^{35}$ Enquiry Report: Fire Incident at Ali Enterprises S.I.T.E Karachi on 11th September 2012. Federal Investigation Agency, Sindh Zone Karachi, 3 October 2012, Court File of Constitutional Petition No. 3318 of 2012, pp. 1311, 1313.

${ }^{36}$ Forensic Architecture, The Ali Enterprises Factory Fire, 30 January 2018, www.forensicarchitecture.org/investigation/the-ali-enterprises-factory-fire (last accessed 15 August 2020).

${ }^{37}$ Enquiry Report: Fire Incident at Ali Enterprises S.I.T.E Karachi on 11th September 2012. Federal Investigation Agency, Sindh Zone Karachi, 3 October 2012, Court File of Constitutional Petition No. 3318 of 2012, pp. 1301, 1311.
} 
However, on the day of the fire, an estimated 885 people were present in the building: 45 in the basement, 40 on the mezzanine floor, 350 on the first floor and 450 on the second floor. The day of the fire was payday for the workers and, at the time the fire began (around 6:30 pm), as many as 500 to 600 workers were on the second floor of the factory, where their payments were being disbursed at the time. ${ }^{38}$

There was no functional fire alarm in the Ali Enterprises factory and the CCTV footage shows that the workers only became aware of the fire approximately $25 \mathrm{~min}$ after it had started. ${ }^{39}$ The Factories Act 1934, and the KBTPR 2002, both require that every factory have effective and clearly audible means of giving warning in case of fire, but this was obviously not the case at the Ali Enterprises factory. ${ }^{40}$ At 6:56 pm, only a minute or two after the workers realised that there was a fire, the electricity supply was shut off. ${ }^{41}$ After this, there was no lighting or emergency markings that could guide the workers to the building's fire exits, despite the fact that this was legally required. ${ }^{42}$ There were not even glow-in-the-dark markings pointing towards the exits. ${ }^{43}$ Smoke and soot further disoriented workers who were trying to escape though the only available staircase leading to the only functional exit: the only way to escape the fire was through the main entrance on the ground floor, accessible only through the main staircase, ${ }^{44}$ which itself was fast disintegrating due to the fire. ${ }^{45}$

\footnotetext{
${ }^{38}$ Enquiry Report: Fire Incident at Ali Enterprises S.I.T.E Karachi on 11th September 2012. Federal Investigation Agency, Sindh Zone Karachi, 3 October 2012, Court File of Constitutional Petition No. 3318 of 2012, pp. 1317, 1337; Forensic Architecture, The Ali Enterprises Factory Fire, 30 January 2018, www.forensic-architecture.org/investigation/the-ali-enterprises-factory-fire (last accessed 15 August 2020).

${ }^{39}$ Enquiry Report: Fire Incident at Ali Enterprises S.I.T.E Karachi on 11th September 2012. Federal Investigation Agency, Sindh Zone Karachi, 3 October 2012, Court File of Constitutional Petition No. 3318 of 2012, p. 1315.

${ }^{40}$ See Section 25 of the Factories Act 1934 and Regulation 13(6.1) of the Karachi Building and Town Planning Regulations 2002. Notably, even when the Factories Act 1934 was updated and re-enacted as the Sindh Factories Act 2015, no specifications for the kind or volume of the fire alarm system to be used were provided, nor were any amendments made in the Sindh Factory Rules 1975.

${ }^{41}$ Enquiry Report: Fire Incident at Ali Enterprises S.I.T.E Karachi on 11th September 2012. Federal Investigation Agency, Sindh Zone Karachi, 3 October 2012, Court File of Constitutional Petition No. 3318 of 2012, p. 1315; Forensic Architecture, The Ali Enterprises Factory Fire, 30 January 2018, www.forensic-architecture.org/investigation/the-ali-enterprises-factory-fire (last accessed 15 August 2020).

${ }^{42}$ Section 19 of the Factories Act 1934 requires that emergency lighting of special points on the factory floors and passages must function automatically in case of a failure of the ordinary electric system.

${ }^{43}$ Section 25 of the Factories Act 1934 and Rule 21 of the Sindh Factory Rules 1975 required that all exits and escape routes be clearly marked in a language understood by the workers and that a free passageway always be maintained to give access to each means of escape in case of fire.

${ }^{44}$ Forensic Architecture, The Ali Enterprises Factory Fire, 30 January 2018, www.forensicarchitecture.org/investigation/the-ali-enterprises-factory-fire (last accessed 15 August 2020).

${ }^{45}$ Enquiry Report: Fire Incident at Ali Enterprises S.I.T.E Karachi on 11th September 2012. Federal Investigation Agency, Sindh Zone Karachi, 3 October 2012, Court File of Constitutional Petition No. 3318 of 2012, p. 1303; Forensic Architecture, The Ali Enterprises Factory Fire, 30 January
} 
There were approximately five emergency exit doors in the building, but none of them could be used to escape the fire. The 500 to 600 workers on the second floor were trapped because the two emergency exit doors on the second floor which led to Block-B as well as the two exits to the roof had been permanently locked by factory management. ${ }^{46}$ When or if these workers reached the first floor, they found approximately 350 other workers trapped there. The two emergency exit doors on the first floor, which were presumably functional towards the very beginning of the fire, had expanded due to heat and become stuck in their frames by the time more workers became aware of the fire. ${ }^{47}$ The exits from the basement only led to the ground floor, which itself was on fire. In the basement, the fire was aggravated and exits were blocked by bales and bales of cloth, which had been wrapped in polyethylene and negligently strewn across the floor. ${ }^{48}$ The Factories Act 1934, requires all materials to be stored safely and emergency exits to always be kept clear of any obstruction. ${ }^{49}$ Moreover, on the first and second floors, there existed doors that looked like emergency exits that might lead to an escape stairwell, but the emergency staircase itself was missing — one would have had to jump straight out of the first or second floor and some workers did jump. ${ }^{50}$ For the most part, the factory's windows had been barred with metal grills, meaning the workers could not jump out of them. ${ }^{51}$ The Factories Act of 1934 and the Sindh Factories Rules of 1975 require that the doors affording exit from any room not be locked and to be kept free from obstructions at all times. ${ }^{52}$ The Factories Act 1934, also requires that every factory building must have adequate means of escape, accessible from every room of the

\footnotetext{
2018, www.forensic-architecture.org/investigation/the-ali-enterprises-factory-fire (last accessed 15 August 2020).

${ }^{46}$ Enquiry Report: Fire Incident at Ali Enterprises S.I.T.E Karachi on 11th September 2012. Federal Investigation Agency, Sindh Zone Karachi, 3 October 2012, Court File of Constitutional Petition No. 3318 of 2012, p. 1317.

${ }^{47}$ Enquiry Report: Fire Incident at Ali Enterprises S.I.T.E Karachi on 11th September 2012. Federal Investigation Agency, Sindh Zone Karachi, 3 October 2012, Court File of Constitutional Petition No. 3318 of 2012, p. 1317; Forensic Architecture, The Ali Enterprises Factory Fire, 30 January 2018, www.forensic-architecture.org/investigation/the-ali-enterprises-factory-fire (last accessed 15 August 2020).

${ }^{48}$ Forensic Architecture, The Ali Enterprises Factory Fire, 30 January 2018, www.forensicarchitecture.org/investigation/the-ali-enterprises-factory-fire (last accessed 15 August 2020).

${ }^{49}$ Section 25 of the Factories Act 1934; Rule 21 of the Sindh Factories Rules 1975.

${ }^{50}$ Enquiry Report: Fire Incident at Ali Enterprises S.I.T.E Karachi on 11th September 2012. Federal Investigation Agency, Sindh Zone Karachi, 3 October 2012, Court File of Constitutional Petition No. 3318 of 2012, p. 1317.

${ }^{51}$ Enquiry Report: Fire Incident at Ali Enterprises S.I.T.E Karachi on 11th September 2012. Federal Investigation Agency, Sindh Zone Karachi, 3 October 2012, Court File of Constitutional Petition No. 3318 of 2012, p. 1337; Forensic Architecture, The Ali Enterprises Factory Fire, 30 January 2018, www.forensic-architecture.org/investigation/the-ali-enterprises-factory-fire (last accessed 15 August 2020).

${ }^{52}$ Rule 30 of the Sindh Factories Rules 1975.
} 
factory, in case of fire but this was evidently not the case. ${ }^{53}$ Moreover, the KBTPR 2002 also requires that all storeys, except for those below the first, should provide direct access for firefighters from the outdoors, but no such access was provided in the AE factory. ${ }^{54}$

There was also an emergency exit on the mezzanine floor, but this mezzanine had a wooden floor that had not been fire-proofed. As a result, it burned down very quickly, casting fiery debris onto the ground floor. ${ }^{55}$ For factory buildings of up to 25 feet $(7.5 \mathrm{~m})$, the law requires that every element of structure, on the ground floor or any upper storey must be fire resistant for $1.5 \mathrm{~h}(90 \mathrm{~min})$, and in the basement for $1 \mathrm{~h}(60 \mathrm{~min}) .{ }^{56}$ It also requires that all steel and metal structures be protected by non-combustible materials. ${ }^{57}$ Moreover, the spread of the fire could have been slowed if the floors had been compartmentalised, as is required by the KBTPR 2002. ${ }^{58}$ The only part of the factory where there was compartmentalisation was the ground floor. While the warehouse on the ground floor was completely burnt in the fire, only around 10 percent of the washing area on the same floor was affected. The FIA Report noted that this was likely due to the presence of a dividing wall and the absence of readily combustible material. ${ }^{59}$

The second floor of the Ali Enterprises factory was significantly more damaged than the first floor. ${ }^{60}$ This was due to the fact that improper ventilation in the

\footnotetext{
${ }^{53}$ Section 25 of the Factories Act 1934; Moreover, the Sindh Factories Rules 1975 require that all factories of more than one storey must have two sets of stairs. One of the stairways should be external, permanently fixed, made of non-combustible materials, fixed with suitable handrails, accessible, easy to open from inside and have direct and should provide unimpeded access to the ground level from every part of the factory in case of fire (Rule 30 and 52 of the Sindh Factories Rules 1975). Furthermore, the Karachi Building and Town Planning Regulations 2002, require that the staircase inside the building should be a minimum width of 4 feet $(1.2 \mathrm{~m})$, and the maximum distance from any point on the floor to the nearest staircase should not be more than 98.4 feet $(30 \mathrm{~m})$ (Regulation 9(8.2) of the Karachi Building and Town Planning Regulations 2002).

${ }^{54}$ According to Regulation 14(8) of the Karachi Building and Town Planning Regulations 2002, this access must be provided for every storey whose floor is less than 82 feet $(25 \mathrm{~m})$ above ground, and the access bust be at least 3.6 feet $(1.1 \mathrm{~m})$ high by 2 feet $(0.6 \mathrm{~m})$ wide, with a sill height of not more than 3 feet $(0.9 \mathrm{~m})$ above the inside floor.

${ }^{55}$ Enquiry Report: Fire Incident at Ali Enterprises S.I.T.E Karachi on 11th September 2012. Federal Investigation Agency, Sindh Zone Karachi, 3 October 2012, Court File of Constitutional Petition No. 3318 of 2012, pp. 1303, 1313, 1317.

${ }^{56}$ Regulation 14(1.2), Table 14.1, Karachi Building and Town Planning Regulations 2002.

${ }^{57}$ Regulation 14(13.1-13.2), Table 14.1, Karachi Building and Town Planning Regulations 2002.

${ }^{58}$ Regulation 14(5) of the Karachi Building and Town Planning Regulations 2002 also requires that the building floor should be compartmentalised as much as possible by means of appropriate fireresistant elements/measures (such as firewalls).

${ }^{59}$ Enquiry Report: Fire Incident at Ali Enterprises S.I.T.E Karachi on 11th September 2012. Federal Investigation Agency, Sindh Zone Karachi, 3 October 2012, Court File of Constitutional Petition No. 3318 of 2012, p. 1301.

${ }^{60}$ Enquiry Report: Fire Incident at Ali Enterprises S.I.T.E Karachi on 11th September 2012. Federal Investigation Agency, Sindh Zone Karachi, 3 October 2012, Court File of Constitutional Petition No. 3318 of 2012, p. 1303.
} 
factory's cargo elevator had created an air channel that carried the fire upwards. The elevator shaft, which was located next to the only staircase in the building, also caught fire. ${ }^{61}$ The cargo elevator was not properly ventilated and there were gaps in the shaft which created a chimney effect, causing the fire to spread to the first and second floors through the elevator shaft. ${ }^{62}$ What was most shocking, however, is that despite the factory building having five storeys, there was only one fire extinguisher in the entire building-which too was empty at the time, and none of the workers knew how to use it. ${ }^{63}$ The Sindh Factories Rules 1975, and the KBTPR 2002, both require that there be at least one fire extinguisher on every floor in the building. ${ }^{64}$ The Factories Act 1934, also stipulates that all workers should know where the emergency exits are located and should be adequately trained to respond to emergencies, including fires, ${ }^{65}$ which was obviously not the case at Ali Enterprises. ${ }^{66}$

Regardless of the fire's cause, if the basic safety precautions and inspections had been conducted, the fatalities at the Ali Enterprises factory could have been minimised and very likely prevented entirely. Nevertheless, the FIA Report explored several possible causes of the fire. It found that the factory's electrical system was errant, unsafe and vulnerable to accidental short-circuiting. ${ }^{67}$ Moreover, the burners for the factory's dryers, which were located on the ground floor, used to be lit

\footnotetext{
${ }^{61}$ Enquiry Report: Fire Incident at Ali Enterprises S.I.T.E Karachi on 11th September 2012. Federal Investigation Agency, Sindh Zone Karachi, 3 October 2012, Court File of Constitutional Petition No. 3318 of 2012, p. 1303; Forensic Architecture, The Ali Enterprises Factory Fire, 30 January 2018, www.forensic-architecture.org/investigation/the-ali-enterprises-factory-fire (last accessed 15 August 2020).

${ }^{62}$ The Karachi Building and Town Planning Regulations 2002 require that the protected shaft containing an elevator must be ventilated; if the opening is at the bottom of the shaft the opening should be as small as practicable and it shall not be constructed of, or lined with, any material which increases the risk of spread of fire. Regulation 14(9.3), Karachi Building and Town Planning Regulations 2002.

${ }^{63}$ Forensic Architecture, The Ali Enterprises Factory Fire, 30 January 2018, www.forensicarchitecture.org/investigation/the-ali-enterprises-factory-fire (last accessed 15 August 2020).

${ }^{64}$ Rule 51 of the Sindh Factories Rules (1975) requires that, for floor space up to 6000 square feet, there must be one chemical extinguisher of two-gallon capacity, and there must be an additional extinguisher for each additional 6000 square feet. According to Regulation 13(3.1.5) of the Karachi Building and Town Planning Regulations (2002), all building compartments more than 7000 square feet in covered area that are used to manufacture, display or sell combustible materials and products must have automated sprinkler systems installed. The Ali Enterprises factory, covering an area of 17,222 square feet (according to the FIA Report) and engaged in the manufacture and storage of garments from flammable cotton and synthetic fibres, but it had no such automated sprinkler system installed.

${ }^{65}$ Section 25 of the Factories Act 1934 and Rule 21 of the Sindh Factories Rules 1975.

${ }^{66}$ Enquiry Report: Fire Incident at Ali Enterprises S.I.T.E Karachi on 11th September 2012. Federal Investigation Agency, Sindh Zone Karachi, 3 October 2012, Court File of Constitutional Petition No. 3318 of 2012, p. 1301; Forensic Architecture, The Ali Enterprises Factory Fire, 30 January 2018, www.forensic-architecture.org/investigation/the-ali-enterprises-factory-fire (last accessed 15 August 2020).

${ }^{67}$ For example, the transformer, LT Panel and generators were all installed in the same room as opposed to being in separate rooms. See: Enquiry Report: Fire Incident at Ali Enterprises S.I.T.E
} 
through a very dangerous manual procedure: a worker would dip a metal rod, wrapped in cotton on one end, into a plastic can full of kerosene oil and light it with a matchstick, and then use the flame to fire up the dryer burners. This contraption (consisting of the wrapped rod and kerosene oil) was kept very close to the warehouse, right above which was the wooden floor of the mezzanine, which was completely burnt in the fire. Eyewitness accounts documented in the FIA Report also suggest that fires caused by this dryer-lighting procedure had erupted in the past but had always been successfully extinguished by the staff. ${ }^{68}$

According to the SBCO, all buildings must have their building plans approved by the SBCA. However, only SITE approved the building plan for the Ali Enterprises factory, and it allowed significantly more built-up area than legally permissible. Yet, even the building plan approved by SITE had not envisaged the factory's second floor. ${ }^{69}$ Legally, it is only after the proprietors have been granted a "No Objection Certificate" (NOC) for construction by the SBCA that they can start building. The SBCO also stipulates that no building can be occupied before the SBCA has conducted an inspection and issued an "Occupancy Certificate," after an application by the occupant or owner. ${ }^{70}$ During the construction, an inspecting engineer or a building supervisor must be engaged and is required to sign off on the building plan. ${ }^{71}$ Moreover, the Factories Act 1934, required that every factory be registered with the Chief Inspector in the Sindh Labour Department, to whom any and all accidents in the factory were to be reported. ${ }^{72}$

However, the Ali Enterprises factory never applied for, much less acquired, an NOC or an Occupancy Certificate. It had never been registered with the Chief Inspector as required by the law, nor had previous fires in the factory ever been reported to the Sindh Labour Department. ${ }^{73}$ When these lapses became public knowledge and, later, came to the court's attention, the SBCA insisted that SITE

Karachi on 11th September 2012. Federal Investigation Agency, Sindh Zone Karachi, 3 October 2012, Court File of Constitutional Petition No. 3318 of 2012, p. 1327.

${ }^{68}$ Enquiry Report: Fire Incident at Ali Enterprises S.I.T.E Karachi on 11th September 2012. Federal Investigation Agency, Sindh Zone Karachi, 3 October 2012, Court File of Constitutional Petition No. 3318 of 2012, p. 1329.

${ }^{69}$ The total area of the plot F/67, on which the Ali Enterprises factory was built, was 4646.34 square yards (41,817.06 square feet). Legally, it was allowed to have a built-up area of 33,454 square feet (80 percent), but SITE approved a plan for 35,947 square feet, while the factory owners actually built a covered area of 52,569 square feet. Enquiry Report: Fire Incident at Ali Enterprises S.I.T.E Karachi on 11th September 2012. Federal Investigation Agency, Sindh Zone Karachi, 3 October 2012, Court File of Constitutional Petition No. 3318 of 2012, p. 1331.

${ }^{70}$ Section 6 of the Sindh Building Control Ordinance 1979.

${ }^{71}$ If there are defects in the structure, plan and construction, then the SBCA is required to determine the liability of the builder/subcontractor and/or their associates. Section 7 of the Sindh Building Control Ordinance 1979.

${ }^{72}$ Section 11 of the Factories Act 1934.

${ }^{73}$ If there are defects in the structure, plan or construction, then the SBCA is required to determine the liability of the builder/subcontractor and/or their associates. Section 7 of the Sindh Building Control Ordinance 1979. 
was responsible, while SITE insisted that the SBCA was also responsible. ${ }^{74}$ In reality, neither authority had physically inspected the building or penalised its illegal constructions. The FIA Report notes that if the building had been properly inspected, "large scale" fatalities could have been prevented. ${ }^{75}$ While SITE bears responsibility for the oversight of the factories operating within it, the SBCA had the primary responsibility to inspect the building structure, as it is the institution charged with enforcing the Sindh Building Control Ordinance of 1979 and the rules and regulations thereunder, including those listed in the KBTPR of 2002. Nevertheless, in March 2013, the High Court of Sindh directed SITE and the SBCA to conduct a specific investigation to "reveal the deviation from the relevant laws, particularly the rules and the regulations," meaning the building and planning laws. ${ }^{76}$ That report also found that the Ali Enterprises factory had never been inspected or approved for occupation, meaning it had deviated from all relevant laws. ${ }^{77}$

Parallel to all these delinquencies, the Ali Enterprises factory and KiK had engaged in certain voluntary regulatory procedures. For instance, a social audit of the factory had been conducted to check the factory for its safety measures etc., and had resulted in the granting of an SA- 8000 certification, less than a month before the fire. It is important to note here that the SA- 8000 certificate was neither mandated under Pakistani law, nor required by German or European law, under which KiK operates. It was a mere trick to provide the factory with a facade of legitimacy, while it actively violated almost all of the OSH standards required to legally operate in Pakistan, ${ }^{78}$ it was merely used to distract from the AE factory's violation of all legally binding OSH regulations.

\footnotetext{
${ }^{74}$ SITE responsible for Baldia factory building plan, says SBCA. The News, 15 September 2012, www.thenews.com.pk/archive/print/385215-site-responsible-for-baldia-factory-building-plansays-sbca (last accessed 2 August 2020); Asian Human Rights Commission, Pakistan: Baldia factory fire tragedy - the compensation is not the only solution to deal with such an incident, 10 September 2014, www.humanrights.asia/news/forwarded-news/AHRC-FST-068-2014/ (last accessed 2 August 2020).

${ }^{75}$ Enquiry Report: Fire Incident at Ali Enterprises S.I.T.E Karachi on 11th September 2012. Federal Investigation Agency, Sindh Zone Karachi, 3 October 2012, Court File of Constitutional Petition No. 3318 of 2012, p. 1331.

${ }^{76}$ Order dated: 12 March 2013, passed in Constitutional Petition No. D-295 of 2013, by the High Court of Sindh.

${ }^{77}$ Compliance Report of the Labour and Human Resources Department of the Government of Sindh, submitted pursuant to Order dated 5 November 2012, passed by the High Court of Sindh, in Constitutional Petition No. 3318 of 2012, Court File p. 317.

${ }^{78}$ ECCHR Case Report, RINA certifies safety before factory fire in Pakistan, November 2016, www.ecchr.eu/fileadmin/Fallbeschreibungen/CaseReport_Rina_Pakistan.pdf (last accessed 3 August 2020).
} 


\subsection{Recent Developments and Continuing Non-enforcement}

During the proceedings regarding the AE factory fire at the High Court of Sindh, it was found that, as of November 2012 (two months after the fire), 7576 factories were registered with the Sindh Labour Department. Of these, 214 factories' registrations (and 180 new Sindh Labour Department inspections) had been prompted by the horrifying fire. ${ }^{79}$ Almost eight years later, however, the Sindh Labour Department still lacks a comprehensive registration of factories, any data collection mechanism, as well as any accurate tally of the number of factories, workplaces other than factories or total number of workers in the province of Sindh, or even in the city of Karachi. According to the Sindh Labour Department, as of August 2020, there were 9868 registered factories, though many of them had yet to be inspected due to a chronic shortage of inspectors and a lack of political will for the enforcement of workplace safety laws and standards. Indeed, in August 2020, there were only 22 labour inspectors for all of Sindh. ${ }^{80}$ A large proportion of factories also remained unregistered as of August 2020, and no official comprehensive data yet exists for workplaces other than factories, such as construction sites, restaurants, cinemas, etc. $^{81}$

While the Factories Act of 1934 only imposed a penalty fine of 500 rupees (2.82 euros) on the employer for any contravention of its provisions, ${ }^{82}$ the purportedly updated Sindh Factories Act of 2015 enhanced and differentiated the penalties, raising them to a range of 10,000 to 50,000 rupees (57.40 to 287 euros). ${ }^{83}$ Thus, the total penalty is still exceedingly minimal. This is particularly significant because

\footnotetext{
${ }^{79}$ Compliance Report of the Labour and Human Resources Department of the Government of Sindh, submitted pursuant to Order dated: 5 November 2012, passed by the High Court of Sindh, in Constitutional Petition No. 3318 of 2012, Court File p. 317.

${ }^{80}$ Interviews conducted with M. Ashraf, Director of the Department of Labour \& Human Resources, Government of Sindh, Karachi, 10 January 2020 and 20 August 2020. According to current practice, each inspector (of 22 in total) does eight inspections per month, amounting to around 1800-2000 inspections carried out per year.

${ }^{81}$ Interviews conducted with M. Ashraf, Director of the Department of Labour \& Human Resources, Government of Sindh, Karachi, 10 January 2020 and 20 August 2020. 37,000 shops and establishments are registered in Sindh.

${ }^{82}$ Sections 39 and 60 of the Factories Act 1934.

${ }^{83}$ Sections $92-101$ of the Sindh Factories Act 2015. At the time of the Ali Enterprises fire, the Factories Act 1934 was still applicable to Sindh as the province had not yet enacted relevant legislation of its own. Over the following years, all four provinces of Pakistan re-enacted the Factories Act (1934) through their own provincial legislatures, more or less without making any substantial changes to the 1934 act. The Government of Sindh passed the Sindh Factories Act (2015), in which Section 114 stipulates that the Sindh Factories Rules 1975 previously enacted under the Factories Act 1934, continue to remain in force. However, further rules are also required to be framed under the Sindh Factories Act 2015, but these have not been framed till date. Therefore, this discussion of the Factories Act 1934 also applies to the Sindh Factories Act 2015 and Sindh Factories Rules 1975 which remain applicable in Sindh today whilst further Rules under the Sindh Factories Act 2015, are awaited.
} 
in the balance of convenience, if enforcing occupational health and safety measures costs an employer any more than the minimal penalties imposed under the inspection regime, it would suit the employers to continue endangering workers. With such low penalties, factory owners essentially lose nothing and anticipate no penal action against themselves if they continue to endanger their workers.

The other mechanism that can potentially enforce a cost on employers is workers' compensation. Under the Workmen's Compensation Act 1923, employers face unqualified liability, with respect to their employees, for any work-related accident, illness, or fatality. However, 87 percent of the Ali Enterprises workers were hired through a third party contractor and were not given any official letter of appointment, even by the contractor. ${ }^{84}$ Hence, even if a worker had been injured at the factory, they would not be able to prove an employment relationship with Ali Enterprises or even with the contractor, which would then not be liable for the injury. ${ }^{85}$

In addition to this, the Provincial Employees Social Security Ordinance $1965^{86}$ states that "if an employer fails to observe rules of safety or hygiene prescribed by or under any enactment applicable to his establishment the Commissioner may [...] increase the employer's rate contribution; provided that such increase shall not exceed twenty percent of the contribution otherwise payable." ${ }^{87}$ From these provisions, it is quite clear that, even if the workers were officially hired and registered by them, if enforcing OSH measures costs an employer more than 20 percent of the contribution they have to make towards the Social Security Institution, it would be more convenient for them to continue endangering workers instead. And they often do just that. It is also important to highlight that there is no coordination mechanism or overlap between the different bodies overseeing Pakistan's fragmented OSH infrastructure (such as the Sindh Employees Social Security Institution, the Sindh Labour Department, the SBCA, etc.).

In the aftermath of the AE factory fire and following significant lobbying efforts from organisations like PILER and NTUF, as well as individual OSH experts, the Government of Sindh passed a relatively expansive, worker-oriented OSH law: the Sindh Occupational Safety and Health Act 2017 (OSH Act). ${ }^{88}$ In addition to this key legislative reform, numerous provincial labour laws were also promulgated after this tragic factory fire, although these were not necessarily in response to it. These new laws were based on the 18th Amendment to the Constitution of Pakistan 1973, which had been passed in 2010 and had removed the subject of labour matters from the federal government and assigned legislative jurisdictions to provincial

\footnotetext{
${ }^{84}$ Farhat A, Baldia Factory Fire Incident 4 years of successful campaign for justice, PILER, December 2016, www.piler.org.pk/wp-content/uploads/2017/02/Brief_Baldia_Factory_Fire-_Inci dent.pdf (last accessed 12 August 2020).

${ }^{85}$ The problem of contractual labour will be discussed in detail in Sect. 5 .

${ }^{86}$ Section 26 of the West Pakistan Employees Social Security Ordinance 1965; Section 27 of the Sindh Employees Social Security Act 2016.

${ }^{87}$ Section 26 of the West Pakistan Employees Social Security Ordinance 1965.

${ }^{88}$ Occupational Safety and Health Act, 2017; The province of Punjab also passed the Punjab Occupational Health and Safety Act 2019 and other provinces are also drafting their own OSH laws.
} 
governments. ${ }^{89}$ In Sindh, where the Ali Enterprises factory fire occurred, the Factories Act of 1934 was essentially re-enacted with very few changes, as was passed as the Sindh Factories Act 2015. ${ }^{90}$ The West Pakistan Employees Social Security Ordinance 1965 was also re-enacted as the Sindh Employees Social Security Act (SESSI Act) 2016. Although these new acts were passed, they only included minor updates and were not based on any new data or qualitative research. ${ }^{91}$

Nevertheless, Sindh's OSH Act, was the first OSH-specific act passed in the country and it made two significant contributions to OSH infrastructure: it created a mechanism to include workers in informing and enforcing OSH practices, and it created a unified OSH law that is not limited to factories or any particular industry, but it is applicable across Sindh, in all sectors. If the act were to be properly implemented, it would significantly improve the OSH situation in the province. Unfortunately, however, its implementation really has yet to begin. If the OSH Act does get implemented, another noteworthy improvement on the current practices that it would bring is that, all workplaces would have to register themselves with the Directorate of Labour after getting approvals from the relevant (building) authority (that is, the SBCA) as well. Indeed, although the OSH Act expressly requires special inspectors, no inspectors have yet even been inducted under the OSH Act. ${ }^{92}$ The OSH Act also stipulates that every workplace must either have an elected Health and Safety Representative or a Health and Safety Committee, depending on its size. ${ }^{93}$ However, since the provincial government has yet to hire inspectors to monitor and enforce the OSH Act 2017, it can safely be assumed that there has been no implementation of these provisions by the subject workplaces either. The OSH Act further requires the Government of Sindh to make rules under the act and, although drafts have been circulating for a long time, as of mid-2020, no rules have been notified by the Government of Sindh..$^{94}$ Finally, the OSH Act also requires that employers allow their occupational safety and health representatives to attend a government-approved health and safety training at least once every two years, for which the employers must bear all of the associated expenses, including paid leave, course fees, room and board, as well as travel expenses. ${ }^{95}$ However, the Government of Sindh has yet to operationalise any such training courses. No data has even been collected by the Sindh Labour Department to identify the number of workplaces that

\footnotetext{
${ }^{89}$ 18th Amendment to the Constitution of Pakistan, 1973, which was passed in 2010.

${ }^{90}$ For example, Section 11 of the Sindh Factories Act 2015 increases the factory registration requirement by adding one more step: factories now need to register with the Chief Inspector and the Labour Department.

${ }^{91}$ Interviews conducted with M. Ashraf, Director of the Department of Labour \& Human Resources, Government of Sindh, Karachi, 10 January 2020 and 20 August 2020.

${ }^{92}$ Section 22 of the Sindh Occupational Safety and Health Act, 2017.

${ }^{93}$ Section 18 of the Sindh Occupational Safety and Health Act, 2017.

${ }^{94}$ Section 10 of the Sindh Occupational Safety and Health Act, 2017.

${ }^{95}$ Section 13 of the Sindh Occupational Safety and Health Act, 2017.
} 
are operating in Sindh and are evading laws, rules and inspections, despite the passage of eight years since the fire and three years since the OSH Act. ${ }^{96}$

Given the state of affairs described above, it is reiterated that the Ali Enterprises factory was not exceptional in its failure to implement relevant OSH laws. It is regular practice for factories and other workplaces to completely circumvent labourand safety-related laws. A large proportion of factories in Karachi operate in the realm of illegality. ${ }^{97}$

Why is there such a large disjuncture between the safety standards that are guaranteed by law (regardless of their inadequacies) and the dangerous working conditions prevalent across the garment industry and other industrial sectors? Based on the aforementioned facts, I argue that that despite passage of the OSH Act of 2017 which is itself a relatively promising law, there is still very little impetus for employers to improve workplace safety within the prevailing politico-economic framework in Sindh and generally in Pakistan. In whatever form they exist, laws are divorced from their implementation. This occurs because the purpose of these laws is not truly to ensure worker safety. The purpose of this rigmarole of laws is to give legitimacy to and fulfil the economic and political ends of the sovereign government, may it be the national government and its trade policies or the provincial government. That is, to provide face value. The author tenatively believes that this can be understood more precisely through the work of Giorgio Agamben, on the concept of bare life and the Homo Sacer, who asserts that there exists no rule of law, no law "in itself." 98 Instead, there is the rule of the lawmaker, evident through the presence and absence of law. For the law-making sovereign, the worker is homo sacer, a zombie whose body is confined and forced to labour, held accountable through the law, but not safeguarded by it. Once this fundamental point is understood in the context of the Ali Enterprises factory fire, it becomes easier to recognise the impediments to workplace safety and then tailor the response accordingly.

\section{Colonial Legacy: History of the Factories Act}

This section posits that workplace safety in Pakistan may be better reckoned with in light of the history of the Factories Act and global political economy. As noted above, the Factories Act $1934^{99}$ as well as the Workmen's Compensation Act of

\footnotetext{
${ }^{96}$ Interviews conducted with M. Ashraf, Director of the Department of Labour \& Human Resources, Government of Sindh, Karachi, 10 January 2020 and 20 August 2020.

${ }^{97}$ When prompted to action, the Labour \& Human Resources Department was able to get 214 factories to register with it by November 2012. However, despite the fact that Pakistan's GDP growth rate went from 4 percent in 2012 to 5.5 percent in 2020, only 424 more factories had been registered in Sindh by August 2020. See Country Profile, World Bank, www.wits.worldbank.org/ CountryProfile/en/PAK (last accessed 15 August 2020).

${ }^{98}$ Agamben (1998), p. 20.

${ }^{99}$ This factory legislation set up the framework for safety standards and aimed for enforcement through inspections. In addition to the provisions of the Factories Act 1934, that have been
} 
1923, governed OSH in Pakistan at the time of the AE fire. Both these laws were passed under British rule, prior to Pakistan's independence in 1947. The history of the Factories Act is particularly dramatic and important for understanding the evolution of $\mathrm{OSH}$ in Pakistan, which was part of a united India and under British rule. Although Indian workers' movements existed and made demands for better working conditions at the time, successive iterations of the Factories Act until the final Factories Act 1934 were passed to facilitate a greater market share for British textile manufacturers in their fight against the manufacturers of British India. ${ }^{100}$

In order to better understand the Factories Act's journey, a brief survey of the history of OSH in Britain is germane (unlike Pakistan). When industrialisation and mass production began gaining a stronghold in England in the mid-1700s, it centred on the cotton and textile industry, and prompted mass urbanisation, as labour was plentiful, cheap and expendable. Much labour at the time was provided by "pauper apprentices" in return for room and board. ${ }^{101}$ During this period, factories became increasingly dangerous, and the number of occupational diseases, injuries and fatalities ran high. As a general rule, workers faced long hours and cruel conditions. ${ }^{102}$ After much public alarm, ${ }^{103}$ the UK parliament passed the Health and

discussed above, Chapter III of this act mandated that provincial governments make rules and standards as to, inter alia, the disposal of waste, ventilation, temperature, artificial humidification, lighting, drinking water, latrines and urinals, spittoons, provision of canteens, workforce eye protection, precautions in case of fire, dangerous fumes, explosive dust, fencing, casing, lifting of machinery, work near machinery in motion, shelters for the workforce to rest, provision of first aid, and so forth. In accordance with this, the Sindh Government promulgated the Sindh Factories Rules 1975.

${ }^{100}$ Gilbert (1982), pp. 357-372.

${ }^{101}$ In England, children formed 40 percent of the population around the second half of the 1700 s. Many of them were impoverished and/or orphan children, who provided a steady source of cheap and expendable labour. Orphans were sent into factories or other employment by the Poor Law authorities, often very far from their homes. The Poor Law required that every local parish take care of its poor: "A 'poor rate' or local tax paid by parish householders was used to help the poor [...] those who were too ill, old, destitute, or who were orphaned children were put into a local 'workhouse' or 'poorhouse'. Those able to work, but whose wages were too low to support their families, received 'relief in aid of wages' in the form of money, food and clothes." Poverty and the Poor Law. Living Heritage/Reforming Society in the 19th Century, UK Parliament, www. parliament.uk/about/living-heritage/transformingsociety/livinglearning/19thcentury/overview/pov erty/ (last accessed 20 July 2020).

${ }^{102}$ For example, in 1784 , there was a fever outbreak amongst workers at cotton mills, which were the most common type of factory in the late eighteenth century. Young girls working in match factories would regularly develop Phossy Jaw, a condition caused by phosphorous fumes. Workers employed in mines developed and often died of lung cancer before the age of 25. Other accidents causing burns, injuries and even blindness were also increasingly common. History of Workplace Health and Safety, www.staysafeapp.com/blog/2019/12/09/history-workplace-health-safety/ (last accessed 20 July 2020).

${ }^{103}$ This was propelled by a progressive philanthropist and mill-owner, Sir Robert Peel. Early Factory Legislation, Living Heritage/Reforming Society in the 19th Century, UK Parliament, www.parliament.uk/about/living-heritage/transformingsociety/livinglearning/19thcentury/over view/earlyfactorylegislation/ (last accessed 20 July 2020). 
Morals of Apprentices Act in 1802, marking the first legislative attempt to regulate health and safety in factories. ${ }^{104}$ In 1819 , amidst a campaign to ban child labour, it passed the Cotton Mills Act. ${ }^{105}$ Then, in response to the Ten Hour Movement, the first Factories Act was passed in $1831 .{ }^{106}$ Yet, none of these early legislative efforts were particularly effective in improving workers' health and safety in England, for many of the same reasons responsible for the later failures of the 1934 and 2015 Factories Acts in Pakistan. At first, the laws lacked enforcement mechanisms. Then, after enforcement mechanisms were established, the UK lacked the institutional capacity to effectively operate and guarantee them.

In England, it was the Factories Act 1833, that established the first enforcement mechanism in the form of a four-person inspectorate to oversee approximately 4000 cotton mills. The inspectorate's task was obviously far bigger than its capacity and, hence, employers generally evaded the law and it remained largely unenforced. ${ }^{107}$ Subsequent iterations of the Factories Act expanded it in scope to include other industries and tighter inspection regimes, ${ }^{108}$ but employers could still avoid

\footnotetext{
${ }^{104}$ This was the first piece of factory legislation and it applied to cotton mills, which were the dominant form of factory in the country. This law required factories to have sufficient ventilation and be kept clean, and to provide adequate clothing and accommodation for apprentices. It also prohibited apprentices under the age of 21 to work longer than $12 \mathrm{~h}$ a day. Early Factory Legislation. Living Heritage/Reforming Society in the 19th Century, UK Parliament, www. parliament.uk/about/living-heritage/transformingsociety/livinglearning/19thcentury/overview/ earlyfactorylegislation/ (last accessed 20 July 2020).

${ }^{105}$ The 1819 law stipulated that children under nine years could not be employed in cotton mills, and children under 16 years could work a maximum day of $12 \mathrm{~h}$. But once again, the means of enforcing such legislation remained a serious problem. Early Factory Legislation. Living Heritage/ Reforming Society in the 19th Century, UK Parliament, www.parliament.uk/about/living-heritage/ transformingsociety/livinglearning/19thcentury/overview/earlyfactorylegislation/ (last accessed 20 July 2020).

${ }^{106}$ The Ten Hour Movement was led by philanthropists (including mill owners), workers and writers, calling for a 10-h workday. The 1831 legislation provided that children between the ages of 13 and 18 could work a maximum of $12 \mathrm{~h}$ daily. It also extended the ambit of factory legislation to include the wool-producing industry as well. The 1833 Factory Act. Living Heritage/Reforming Society in the 19th Century, UK Parliament, www.parliament.uk/about/living-heritage/ transformingsociety/livinglearning/19thcentury/overview/factoryact/ (last accessed 20 July 2020).

${ }^{107}$ Public opinion, influenced in part by popular writers like Charles Dickens, was able to influence subsequent legislation relating to guarding machinery and reporting accidents. Steadily, the number of factory inspectors grew to 35 in 1886. History of Workplace Health and Safety, www. staysafeapp.com/blog/2019/12/09/history-workplace-health-safety/ (last accessed 20 July 2020).

108 “[T] he Factory Acts (Extension) Act of 1867, took the important step of applying existing legislation to all other factories where 50 or more people were employed. It also brought regulation to other specified industries regardless of numbers employed, namely, blast furnaces, iron and steel mills, glass, paper making, tobacco, printing and bookbinding." The Later Factory Legislation. Living Heritage/Reforming Society in the 19th Century, UK Parliament, www.parliament.uk/about/ living-heritage/transformingsociety/livinglearning/19thcentury/overview/laterfactoryleg/ (last accessed 20 July 2020); Other than Factories Acts, the first Chimney Sweeps Act was passed in 1834, and revised in 1840 and in 1863 . However, this legislation also lacked enforcement mechanisms, until the Chimney Sweepers Act 1875, was passed and it mandated sweepers to be licensed and made it the duty of the police to enforce all previous legislation. Additionally, the Mines and
} 
responsibility for fatalities, injuries or diseases by simply blaming the affected worker or their fellow worker for any mishap. Accordingly, employers continued to endanger workers with impunity. However, inspection regimes became more potent when they were supplemented by the Workmen's Compensation Act of 1897; this stipulated that in case of any accident, injury or disease, the employer would be responsible for covering costs by default, without the injured person having to prove their case against the employer. ${ }^{109}$ By the 1870s, British manufacturers, especially in the cotton and textile industries, had begun to feel the pinch of having to follow health and safety regulations and were ready to do something about it. ${ }^{110}$ British cotton and textile factories were also suffering stiff competition from the colonies, particularly from British India. ${ }^{11}$

To counter this threat, British textile interests took two actions. First, they pushed the British government to remove import duties in the name of free trade and trade liberalisation. Second, they pushed for legislation similar to the Factories Act to be adopted in British India in what Marc Gilbert has described as "a cynical proposal that, under the guise of improving working conditions in the subcontinent, would have increased Indian production costs while reducing output, thus making British manufacturers more prevalent and competitively priced in South Asian bazaars." 112 As a result of these efforts, the UK practically abolished Indian import duties in 1879. Following this victory, British textile interests tried to co-opt the Indian Millhands' Association's (and others') appeal for factory reforms, by advocating for stringent regulation of factories in British India. In 1881, pilot Indian factory legislation was passed as the 1881 Indian Factories Act. ${ }^{13}$ Encouraged by this, the British textile interests continued to push for enough OSH regulation to rob British India of its competitive advantage. ${ }^{114}$

In the face of British textile interests' adversarial efforts, the Indian Millhands' Association came to agree with Indian factory owners: that factory reform and labour protection were required, but not according to the dictates of British interests.

Collieries Act 1842, was passed in the wake of public outcry at the conditions of women and children employed by the mining industry. Nevertheless, the number of accidents continued to rise until the Coal Mines Regulation Act 1872, stipulated that pit managers must have state certification of their training and miners were given the right to appoint inspectors from amongst themselves. Coal Mines. Living Heritage/Reforming Society in the 19th Century, UK Parliament, www. parliament.uk/about/living-heritage/transformingsociety/livinglearning/19thcentury/overview/ coalmines/ (last accessed 20 July 2020).

${ }^{109}$ Poverty and the Poor Law. Living Heritage/Reforming Society in the 19th Century, UK Parliament, www.parliament.uk/about/living-heritage/transformingsociety/livinglearning/ 19thcentury/overview/poverty/ (last accessed 20 July 2020).

${ }^{110}$ Gilbert (1982), pp. 357-372.

${ }^{111}$ Gilbert (1982), pp. 357-372.

${ }^{112}$ Gilbert (1982), p. 359.

${ }^{113}$ Gilbert (1982), pp. 357-372.

${ }^{114}$ The most influential document in the push for further legislation was the report of the Bombay Factory Commission of 1885, which was prepared during the governorship of Sir James Fergusson, a strong proponent of British textile interests in Asia. Gilbert (1982), pp. 359-360. 
Rather, they believed that labour protection should be balanced with the need to protect India's economic integrity. ${ }^{115}$ Indian workers, represented by the Indian Millhands' Association, severely criticised the Factory Act of 1881. Though they unequivocally demanded improved working conditions, ${ }^{116}$ they did not approve of British manufacturers' suggestions: "We do need factory legislation, but certainly not on the lines indicated by Manchester. We want to encourage and protect the industry and not to hamper it. Manchester is indeed extremely kind to our work people, but it is the kindness that kills." ${ }^{117}$ Instead, they demanded improved working conditions that would be economically viable and could ensure long-term job security for workers in India (and could be progressively improved as the Indian economy grew further). Ultimately, the British "decided to apply to India the political formula [they] favored in Europe - the use of more sympathetic administration and the slow but gradual sharing of power with the middle class to co-opt more rapid and radical change." 118

In March 1890, the International Labour Conference in Berlin (Berlin Labour Conference) passed resolutions with respect to working conditions in Europe, which the British delegates signed. ${ }^{119}$ The British textile interests took advantage of this development as an opportunity to reject the new factory legislation being proposed in India at the time, demanding instead that it be aligned with the resolutions of the Berlin Labour Conference. As Gilbert notes, "[t]hese assertions were backed not by appeals from Indian labour or British Progressives but by a letter from the secretary of the Blackburn and District Chamber of Commerce to the Secretary of State for India urging that 'there should not be one law for England and another for India'." Eventually, the Factories Act of $1891^{121}$ was passed in accordance with the Berlin Labour Conference standards with respect to working age and hours of labour, rest and refreshment. ${ }^{122}$

It is apparent that, since the beginning, workers' interests and OSH laws have not been aligned. Although the Indian Millhands' Association raised its voice on behalf of workers, it was not their appeals that led to the promulgation of the law, nor was the voice of British progressives relevant for the implementation or amendment of the law. Rather, it was British textile interests, as allies of the sovereign, who were not only more audible, but more effective in achieving their aims. It also shows that

\footnotetext{
${ }^{115}$ Gilbert (1982), pp. 357-372.

${ }^{116}$ Their key demands included one holiday a week and a midday break period. Gilbert (1982), pp. 357-372.

${ }^{117}$ Gilbert (1982), p. 363.

${ }^{118}$ Gilbert (1982), p. 361 .

${ }^{119}$ These established the need for a compulsory holiday every week (on Sunday), fixing the minimum age for children (10), and setting maximum hours of child labour (six with a half-hour rest interval) and female labour (11 with two hours of rest). Gilbert (1982), pp. 357-372.

${ }^{120}$ Gilbert (1982), p. 365.

${ }^{121}$ Act No. XI of 1891.

${ }^{122}$ Gilbert (1982), p. 365.
} 
workers' interests, related to OSH or otherwise, are not universally identical, but may need to be tailored to their particular context. Transnational solidarity among workers should be excepted from this but the top-down enforcement of purportedly universal OSH standards, particularly in this context, can unsettle or counteract ongoing local movements for betterment (of working conditions), and give way to unsustainable or ineffective mechanisms for improvement whilst silencing the most urgent needs. The Berlin Labour Conference was relevant and useful for the European workers, and was the cumulative result of developments in Europe since the eighteenth century. ${ }^{123}$ However, applied to Indian workers and factory owners, these same developments threatened to make their conditions worse by possibly costing them their jobs, potential for advancement or more jobs through economic growth. If their voice had not been banished and had their safety been regulated through changes reflective of and responsive to Indian factory owners, the workers and the Indian economy's changing needs and priorities, they may have taken ownership of these regulations. Unlike the gradual but sustained growth of OSH in Britain, various British laws were simply imposed onto the Indian landscape over the course of a few decades. This precluded local ownership of workplace safety, by both workers and employers, from taking root. It co-opted the local movement, and generally thwarted substantive improvements in workplace safety.

Nevertheless, despite the British textile interests' attempt to sabotage it, the Indian textile industry, particularly the Bengal jute industry, continued to compete with British manufacturers. This prompted yet another push for factory legislation, in which British manufacturers demanded improved working conditions for Indian workers. In 1911, a newer, more stringent factory legislation was enacted. ${ }^{124}$ A little more than two decades later, the Factories Act 1934 was passed.

Following Pakistan's independence, the Factories Act 1934 has remained applicable across the country. As noted above, it was even re-enacted, without any notable changes, as the Sindh Factories Act 2015, as well as provincial Factories Acts across Pakistan. This continuation of the British law is representative of what Bronwen Manby identifies as the postcolonial states' predilection for half-baked ideas: "The colonial period was both long enough to do very serious damage to pre-existing institutions of government, and too short to create strong new institutions [...] post-colonial history shows how difficult it has been to create a functioning polity [...] how surprisingly persistent is the attachment to the units created by the colonizers." 125 Additionally, it is also quite possible that the colonial laws were kept in place with a strategic purpose. This also allowed the postcolonial state of Pakistan, which occupies a marginalised position in the global economic and

\footnotetext{
${ }^{123}$ Gilbert (1982), p. 367.

${ }^{124}$ During this period, even editorials in The Times newspaper (London) asked point blank if it was "true philanthropy or political immorality for England to interfere with industries which fed millions of men, women, and children." Gilbert (1982), p. 366.

${ }^{125}$ Manby (2009), p. 4.
} 
political order, to protect international trade interests, by continuing to have a British-approved OSH law in place. In addition to this, the Factories Act 1934 promised much beyond what new state of Pakistan had the institutional capacity to deliver, hence, it allowed the state to show its bona fide intentions without actually attempting to, even progressively, deliver on worker safety. To this day, law in "the postcolonial modern state remains steadfastly a European construction." "126 The postcolonial sovereign imitates the coloniser; it dehumanises its own subjects and, in this instance, betrays the truth about its lowly prioritisation of labour protection and safety. ${ }^{127}$ As a result, the OSH infrastructure in Pakistan is disjointed from economic, political, institutional and social realities in that it promises us everything in law, but provides nothing in fact. "Through their uncritical commitment... postcolonial states are complicit" in their own fate and plight. ${ }^{128}$

Perhaps because it was never locally rooted, ${ }^{129}$ Pakistan's OSH infrastructure has been easy for the sovereign state to suspend: to make it present or absent as needed. During times of economic or political upheaval, the country's OSH infrastructure is simply abandoned through non-enforcement and fragmentation of the labour force. While the actions of Pakistani organisations like PILER and NTUF, which were able to achieve significant successes in the aftermath of the AE factory fire, are very important and commendable, they are isolated efforts and, ultimately, no substitute for mass labour action. Though such organisations can potentially cajole state institutions and other stakeholders to achieve formal and or isolated successes, they lack the power that comes with mass labour mobilisation. ${ }^{130}$ Despite their best intentions, they work within the constraints of the prevailing global order: "the agentic role prescribed to NGOs is [...] one that foretells a reworking of democracy in ways that coalesce with global capitalist interests [. . . NGOs remain trapped within an atheoretical framework of state versus civil society." ${ }^{131}$ Neoliberal

\footnotetext{
${ }^{126}$ Otto (1996), pp. 337-338.

${ }^{127}$ Otto (1996), pp. 337-338; Ahmed K, Human Rights and the Non-human Black Body. Sur International Journal on Human Rights, December 2018, www.sur.conectas.org/en/human-rightsand-the-non-human-black-body/ (last accessed 3 August 2020).

${ }^{128}$ Manby (2009), p. 4.

${ }^{129}$ It is important to note that (postcolonial) Pakistan has heavily ostracised and brutalised bona fide trade unions. The Trade Unions Act (1926) passed by the British is still in force and has even been supplemented by the Industrial Relations Ordinance (1969). Laws aside, however, practical representation of workers' own voices is extremely limited. This marginalisation of trade unions is part of a global trend, but that discussion is beyond the scope of the present paper. See Khalil and Khan Z, A Profile of Trade Unionism and Industrial Relations in Pakistan. ILO, 2018, www.ilo.org/ wcmsp5/groups/public/\%2D\%2D-asia/\%2D\%2D-ro-bangkok/\%2D\%2D-ilo-islamabad/docu ments/publication/wcms_626921.pdf (last accessed 22 July 2020).

${ }^{130}$ While NTUF is also registered as a trade union with the National Industrial Relations Commission, it primarily operates as an NGO. PILER is an NGO, albeit led by former trade unionists. Both organisations work within the global trend of increasing constraints on NGOs, but both continually work towards strengthening labour movements and facilitating national trade unions that can take power into their own hands.

${ }^{131}$ Kamat (2004), p. 156; See also, Brown et al. (2007), pp. 126-138.
} 
interests view the rise of NGOs as a step towards democracy, but their "ascendancy can be traced to the end of the Cold War and the launch of the global free market."132

\section{Ruse of Development: Core, Periphery and Global Production}

The contemporary global economy is essentially dichotomous. ${ }^{133}$ For the purposes of this chapter, I will refer to countries of the Global North as "core" countries/states/ economies, and to countries of the Global South as "peripheral" countries/states/ economies; this terminology is based on the works of Raul Prebisch, Andre Gunder Frank's dependency theory and Immanuel Wallerstein's world-systems analysis. ${ }^{134}$ As opposed to the liberal economic theory, which holds sway over the ordering of the contemporary global world order, and claims that liberalised international trade allows countries to benefit from their comparative advantages and hence is advantageous to all,

the concept of core-periphery views international trade as being an "unequal exchange" with surplus value flowing in one direction only, i.e. from the periphery (the Third world) to the core (the developed world). For the dependency theory, the free trade promoted by the core states and their multinational corporations renders the periphery ever more dependent and results in a "development of underdevelopment". ${ }^{135}$

In a nutshell, the core countries wield political and economic power. The peripheral countries are, as the name suggests, on the margins of global politics and economics. They provide cheap and expendable labour and low-cost manufacturing, thus making vast profits possible for the core economies. ${ }^{136}$ This power imbalance allows risk to be outsourced, such as it was to the Ali Enterprises factory, which produced garments for the German company KiK. ${ }^{137}$ Through this usage of "core" and "periphery," In using this dichotomous terminology, I also mean to evoke the peripheral existence of homo sacer, arguing that workers are the marginalised and

\footnotetext{
${ }^{132}$ Kamat (2004), p. 158.

${ }^{133}$ Chossudovsky (1979), pp. 61-62.

${ }^{134}$ For an overview of this "of core-periphery" terminology's historical development, see Spindler (2013).

${ }^{135}$ Spindler (2013), p. 177.

${ }^{136}$ Hitchings-Hales, Hundreds of H\&M and Gap Factory Workers Abused Daily: Report. Global Citizen, 5 June 2018, www.globalcitizen.org/en/content/hm-gap-factory-abuse-fast-fashionworkers/ (last accessed 23 July 2020); Puplampu and Quartey (2012), pp. 151-156.

${ }^{137}$ The dichotomy between the centre economies and the peripheral economies is not a simple binary. There are at least two more variations that disrupt this dichotomy: such as, local manufacturers and profiteers in the peripheral countries (i.e. those who exploit the cheap and expendable labour in their countries), and marginalised workers in the core countries who are deprived of the working conditions associated with and pioneered by the core, and are denied fair wages or the right to association i.e. to form a trade union. See Orleck (2018).
} 
voiceless homo sacer within both the global political economy and the peripheral state itself. ${ }^{138}$ Gayatri Spivak noted that there is an entire mass of people who are illegible, inaudible and invisible; she referred to them as the "subaltern." 139 Building on this, Diane Otto showed that even when we engage in conversations about the power struggle between core and peripheral states, such as in the Third World Approaches to International Law (TWAIL) discourse, we often ignore the subaltern that resides within these states. ${ }^{140}$

Although they were common in the past, ${ }^{141}$ today large industrial disasters and grave workplace hazards are significantly less frequent in core (developed) countries than they are in peripheral countries like Pakistan. ${ }^{142}$ Due to improved OSH and labour conditions, manufacturing costs increased over time in core countries, eventually leading to an overwhelming proportion of manufacturing (and hence the risk of workplace accidents and diseases) being outsourced to the peripheral (developing) countries. $^{143}$

${ }^{138}$ Otto (1996), pp. 337, 341.

${ }^{139}$ Morris and Spivak (2010). The term "subaltern" was first used by Antonio Gramsci (1971). See also Louai (2012).

${ }^{140}$ Otto (1996), pp. 337-338.

${ }^{141}$ For example, employers in the US consistently endangered workers through the eighteenth century. Although the first factory and railroad commissions were made around 1860-61, they were ineffective and powerless. It took big disasters before employers and government recognised need for safer workplaces, such as the 1860 Pemberton Mill collapse in Massachusetts which took 145 lives and injured another 166 and became a rallying point for improved safety standards and in 1877. Massachusetts was the first state in the US to pass a factory inspection law. The first federal law requiring safety equipment at the workplace, the Safety Appliance Act (applicable only to the railroad system) was passed in 1893. The 1878 Washburn "A" Mill explosion in Minneapolis took 18 lives, but new milling technology and safety standards were introduced thereafter. And it was in the aftermath of the Monongah Mine explosions of 1907, which claimed 361 lives, that the US government established the first United States Bureau of Mines in 1910, to oversee mine safety. After the 1911 Triangle Shirtwaist Factory disaster in New York and the death of 146 workers for the first permanent commission to inspect factory safety to be set up. See MacLaury J, The Job Safety Law of 1970: The Passage Was Perilious. US Department of Labour, March 1981, www.dol. gov/general/aboutdol/history/osha (last accessed 10 May 2020); Workers, and notable journalists, photographers and writers, agitated forcefully during the first 30 years of the twentieth century, resulting which there was widespread adoption of compensation laws which imposed liabilities on employers. In 1908, federal railroad workers, and in 1910, New York State got workmen's compensation law, followed by 44 more states through 1921. During his election campaign, President Woodrow Wilson (1913-1921) was the first to promise safer work conditions to workers and, in 1913, the Department of Labor was established under his government. See Occupational Health and Safety Administration, Can't take no more, 1980, www.youtube.com/watch? $\mathrm{v}=13 \mathrm{gzGkQtVzg}$ (last accessed 6 June 2020).

${ }^{142}$ Workplace accidents are 10 times more likely to occur in a developing country, while fatality rates in workplace accidents that do occur in developed countries are only half that of those that occur in of developing countries. See ILO Estimates Over 1 Million Work Related Fatalities Each Year, ILO, www.ilo.org/global/about-the-ilo/newsroom/news/WCMS_007969/lang\%2D\%2Den/ index.htm (last accessed 9 May 2020).

${ }^{143}$ Feenstra (1998), pp. 499-500. 
OSH is usually discussed as a normative concern for developing safe and conscientious workplaces with the support of technical expertise, however, the economic viability of OSH mechanisms plays a key role. ${ }^{144}$ For example, in the United States, OSH standards are frequently subjected to a cost-benefit analysis. ${ }^{145}$ Indeed, several safety and health regulations proposed by the US Department of Labor have been blocked or influenced due to the consideration of free market guidelines in the decision-making criteria. ${ }^{146}$ In Germany, alternatively, OSH standards are primarily set by technical experts, along with the federal and local governments, in a political environment that prevents economics from playing a direct role in standard setting. ${ }^{147}$ While OSH standards themselves may remain relatively untainted by economic considerations in Germany, unlike the US, there are no bars in either country, or generally in any country in the Global North, against outsourcing OSH risks to other countries like Pakistan, where OSH and labour rights stand abducted. ${ }^{148}$ This reinforces the difference between the core and the periphery, as otherwise unbending norms and principles disappear precisely when the coreperiphery relation of production comes into being.

\footnotetext{
${ }^{144}$ Klimnik (1988), pp. $162-165$.

${ }^{145}$ Klimnik (1988), pp. $165-167$. Historically, US courts have had a key role in determining whether OSH or other labour legislation is enforced or outlawed (based on economic beliefs). Roughly during the same period, from 1897 to 1937, the US Supreme Court was also suffering through what became known as the Lochner Era, where it was striking down any attempts made by the government to regulate the manufacturing processes to make them safer and more just for workers. The Lochner Era is understood to begin with Allgeyer v. Louisiana, 165 U.S. 578 (1897), in which the court struck down state legislation prohibiting foreign corporations from doing business in the state because it was deemed to be violating an individual's liberty of contract. It was the first case in which the Supreme Court interpreted the word liberty in the Due Process Clause of the Fourteenth Amendment (which was one of the three amendments that abolished slavery and declared all persons born or naturalized on American soil to be equal citizens before the law) to mean economic liberty. This era came to an end with the case of West Coast Hotel Co. v. Parrish, 300 U.S. 379 (1937), in which the Supreme Court overturned its own previous decision in Adkins v. Children's Hospital, 261 U.S. 525 (1923), and upheld minimum wage legislation, stating that it was valid and did not impinge upon the freedom to contract.

${ }^{146}$ Klimnik (1988), pp. 165, 167 (footnote 135, 136). "The threat of judicial review often eliminates controversial parts of regulations in the United States." Several regulations are delayed for years before they become effective. 167. See Industrial Union Dep't v. American Petroleum Inst., 448 U.S. 607 at 639 (1980) (benzene standard held invalid.) OSHA stayed the publication of lists of potential occupational carcinogens in the wake of the Industrial Union Department. Also See 48 Fed. Reg. 243 (1983); 47 Fed. Reg. 187 (1982). 29 C.F.R. § 1990.121 note (1986).

${ }^{147}$ Klimnik (1988), p. 166.

${ }^{148}$ Meyer (2018), pp. 499-505.
} 


\subsection{Pakistan: Postcolony in the Global Political Economy}

As a peripheral country, the terms of Pakistan's statehood are determined by the core. ${ }^{149}$ Low-cost manufacturing in peripheral (developing) countries is possible because the costs, of safe workplaces and adequately remunerated labour, are avoided. Although laws are in place to ensure both safety and remuneration, there is no enforcement of these laws and the penalties for violating them are minimal. ${ }^{150}$ After independence in 1947, Pakistan sought to modernise its economy. This ambition was at its peak during the dictatorship of Field Marshall Ayub Khan (1958-1968); both the economy and the political structure were geared towards earning the favour of the US. ${ }^{151}$ In the race to improve economic growth, the liberal "trickle down" approach to prosperity was enthusiastically adopted during the rule of General Ayub Khan. ${ }^{152}$ This ambition cost labour protections and safety, ${ }^{153}$ as labourers' demands for better protections kept getting pushed further and further to the side lines. ${ }^{154}$

Although workers movements gained some strength after the independence of Pakistan, and various labour-friendly laws were passed during the 1960s and $1970 \mathrm{~s},{ }^{155}$ their enforcement remained subservient to national economic interests, which sought to catch up with the core economies, that in turn, aimed to instrumentalise these interests. The state's tolerance for labour movements and its willingness to placate workers was intermittent-and laced with its brutalisation of

\footnotetext{
${ }^{149}$ Otto (1996), p. 337.

${ }^{150}$ Chossudovsky (1979), pp. 61-62. For the garment industry, the rough breakdown is that the foreign companies make 90 percent of the profits, while the local manufacturers get nine percent of the profits and workers get one percent. Orleck (2018), p. 164.

${ }^{151}$ Afzal (2007), p. 725; Child and Kaneda (1975); Ahmed (1974).

152،"Pakistan's economy experienced exceptional and spectacular growth rates in all sectors of the economy, which were the outcome of the 'functional inequality' growth strategy, highly protective industrial policy and US experts' direct involvement in the planning process. There was enviable growth, but it did not adequately trickle down to the poorer sections as well as regions". Afzal (2007), p. 725.

${ }^{153}$ Afzal (2007). See also Trickle Down Approach and its Efficacy. Dawn, 8 June 2009, www. dawn.com/news/838887/trickle-down-approach-and-its-efficacy (last accessed 3 May 2020).

154،"The International Labour Organisation (ILO) review mission of 1986 found that as far as the Right of Association was concerned, Pakistani law excluded 75 per cent of the workforce from the Right of Association. And the remaining 25 per cent could not access this right without difficulties." See Sumbul and Ali, Labour Movement in Pakistan. Alternatives International, 1 June 2017, www. alterinter.org/?Labour-Movement-in-Pakistan (last accessed 12 May 2020).

${ }^{155}$ Examples include the West Pakistan Employees' Social Security Ordinance (1965), the Industrial Relations Ordinance (1969), the West Pakistan Industrial and Commercial Employment (Standing Orders) Ordinance (1968), the West Pakistan Shops and Establishments Ordinance (1969), the Workers' Welfare Fund Ordinance (1971), and the Employees' Old-Age Benefits Act (1976).
} 
labour struggles. ${ }^{156}$ In the more recent decades after the Cold War, workers movements in Pakistan have been completely destabilised due to intrusive policies adopted by institutions like the World Bank and the International Monetary Fund, and their Structural Adjustment Programs, as well as the EU's GSP+ programme. ${ }^{157}$

\subsection{Rising Trade Liberalisation and Falling Worker Safety: Pakistan Since the Cold War}

On the global front, when the Cold War ended, it appeared that capitalism had triumphed and newly independent or recently decolonised peripheral countries marched to legitimise themselves as liberal democracies. ${ }^{158}$ Becoming a bona fide liberal democracy, that is truly open to aspirations of trade liberalisation and the accompanying baggage, became the undisputed ideal for all countries in the postCold War period. As a result, institutions that could facilitate the achievement of this ideal, such as the World Bank, IMF, World Trade Organization and relevant programmes of the European Union also gained more power. ${ }^{159}$ The IMF and the World Bank extend large loans to peripheral countries purportedly to facilitate their development into robust liberal democracies. After these peripheral countries are deeply and inextricably indebted, the IMF and World Bank buy or forgive their debts in return for these countries make it "easier, cheaper and more profitable for foreign companies to invest." 160 Therefore, it is extremely important that the non-enforcement of labour laws described above should be viewed as part of a larger "imperial international economic policy" being implemented by the core countries through institutions like the IMF, World Bank and WTO.

Essentially, this policy is "concerned with (a) the regulation of trade and of the international monetary system; and (b) the monitoring of capital flows and 'foreign aid' between core and periphery." ${ }^{\text {"61 }}$ Within this policy, the IMF has played a particularly key role in monitoring the economic policies of peripheral states, while the core countries have benefitted immensely. The global textile and garment

\footnotetext{
${ }^{156}$ Military dictatorships passed favourable laws, while mainstream political parties such as the Pakistan People's Party (PPP) also co-opted the rhetoric of the labour movement and ran election campaigns for the December 1971 election on the promise of land and labour reforms. See Pakistan Forum (1972).

${ }^{157}$ See Sumbul and Ali, Labour Movement in Pakistan. Alternatives International, 1 June 2017, www.alterinter.org/?Labour-Movement-in-Pakistan (last accessed 12 May 2020).

${ }^{158}$ Hobson (2009), p. 383.

${ }^{159}$ Sheth (1995), p. 35; Hobson (2009), p. 384.

${ }^{160}$ Orleck (2018), p. 125.

${ }^{161}$ Chossudovsky (1979), p. 64.
} 
industry provides a prime example of this trend, as it "tripled in size and value between the years 2005 and 2015."162

Wielding this bolstered power, institutions like the IMF or World Bank etc. Have been able to ensure the aggressive theoretical deployment and practical abduction of occupational health and safety infrastructures ${ }^{163}$ coupled with the liberalisation of economies to make them more amenable to foreign investment. ${ }^{164}$ As this post-Cold War trade liberalisation gained a foothold in Pakistan, the state also began to suspend worker safety that was ostensibly guaranteed by law (at least in factories). As Mohammad Afzal describes it:

Pakistan started liberalising the economy with the help of IMF and World Bank in 1982-83 [...] The process of liberalisation started during 6th Five-Year-Plan (1983-88) and was implemented with great force after 1988. The government pursued vigorous trade liberalisation in the beginning of 1990s to convert the economy from a relatively inward looking to an open and outward looking economy. Government has taken a number of measures during 1990s that includes: privatisation, liberalisation of trade and foreign exchange, and opening up its capital markets to foreign investors [...] to integrate its economy with rest of the world. ${ }^{165}$

In 1986, the IMF's Structural Adjustment Programs first came to Pakistan and obliged the country to engage in progressive privatisation (particularly) of public goods and open itself to liberalised international trade. At the same time, unannounced factory inspections were suspended in order to encourage trade (and discourage worker safety). According to PILER's Executive Director, Karamat Ali, General Zia-ul-Haq, who governed Pakistan from 1977 to 1988, even "formally announced that no inspection could take place without the concurrence of the employer. The 1986 ILO review mission on health and safety said that going by the current capacity of the inspectorate, a factory inspected in 1986 would only get its next turn for inspection after 30 years." ${ }^{, 166}$ Then, in the early 2000 s, there came a new wave of trade liberalisation under the regime of General Pervez Musharraf. Through new industrial policies that remain shrouded in mystery to this day, safety

\footnotetext{
${ }^{162}$ Orleck (2018), p. 126.

${ }^{163}$ Swaroop V, World Bank's Experience with Structural Reforms for Growth and Development. World Bank, May 2016, www.documents.worldbank.org/curated/en/826251468185377264/pdf/ 105822-NWP-ADD-SERIES-MFM-Discussion-Paper-11-PUBLIC.pdf, p. 2 (last accessed 6 August 2020); Pasha H, GSP Pus Status and Compliance of Labour Standards. Friedrich-EbertStiftung, November 2014, www.library.fes.de/pdf-files/bueros/pakistan/11046.pdf (last accessed 4 August 2020).

${ }^{164}$ Trade liberalisation refers to the removal of tariffs and non-tariff barriers to trade so that economies can be integrated into the global economy. See IMF Staff, Global Trade Liberalization and Developing Countries. International Monetary Fund, November 2001, www.imf.org/external/ np/exr/ib/2001/110801.htm (last accessed 23 May 2020).

${ }^{165}$ Afzal (2007), p. 726.

${ }^{166}$ See See Sumbul D and Ali K, Labour Movement in Pakistan. Alternatives International, 1 June 2017, www.alterinter.org/?Labour-Movement-in-Pakistan (last accessed 12 May 2020).
} 
inspections were suspended. ${ }^{167}$ Both General Zia-ul-Haq and General Musharraf's policies made it easier and cheaper for local manufacturers to set up or operate factories and to produce for foreign buyers. Meanwhile, workers suffered, poverty rose, and quality of life fell, particularly throughout the 1990s when access to education, health and housing decreased. ${ }^{168}$ Local labour movements in many peripheral countries were further destabilised by the fact that workers could no longer raise their voices as a unified front because unionisation was heavily discouraged and penalized. ${ }^{169}$ In Pakistan, workers' movements that were struggling for better and more equitable working conditions were suppressed, often brutally. ${ }^{170}$ Workplaces became increasingly unsafe, terms of employment changed, and workers' jobs were contractualised en masse. ${ }^{171}$

\subsection{Utopian Aspirations and Dystopian Actions}

Based on the above discussion, I argue that peripheral countries are not considered part of the "human world," but essentially as savage peoples living on the margins of human civilisation. ${ }^{172}$ Therefore, peripheral countries (are required to) maintain blind fidelity to formal structures, such as OSH laws that imitate and monkey liberal democracies of the core, but they are equally required to not have fidelity to the substantive content signified by these formal structures, that is, in this case to worker safety. In order to be considered civilised and to participate global politics, peripheral states must regurgitate the ideals and formal structures of the core. Yet, in order to survive global economics, they must abandon these purportedly universal norms and principles to get their hands dirty. The form of OSH infrastructure developed by former colonial masters and powerful liberal democracies has become entrenched as the universal yardstick and aspirational blueprint blindly adopted or continued by countries like Pakistan. ${ }^{173}$ When laws, standards or mechanisms that mirror core countries are adopted in Pakistan, they are considered laudable, regardless of whether it is institutionally possible to implement them or whether they sustainably and realistically address its needs. It appears that there is comfort in promising

\footnotetext{
${ }^{167}$ Ijaz S, No Room to Bargain. Human Rights Watch, 23 January 2019, www.hrw.org/report/2019/ 01/23/no-room-bargain/unfair-and-abusive-labor-practices-pakistan (last accessed 12 August 2020); Enquiry Report: Fire Incident at Ali Enterprises S.I.T.E Karachi on 11th September 2012. Federal Investigation Agency, Sindh Zone Karachi, 3 October 2012, Court File of Constitutional Petition No. 3318 of 2012, p. 1333.

${ }^{168}$ Afzal (2007), p. 726.

${ }^{169}$ Orleck (2018).

${ }^{170}$ Pakistan Forum (1972), pp. 13-16; Ali (2005), pp. 83-107.

${ }^{171}$ Orleck (2018).

${ }^{172}$ Mbembe (2003); Deleuze and Guattari (1980), p. 445.

${ }^{173}$ Hobson (2009), p. 383.
} 
everything. And because it is impossible to deliver that everything, the promise alone has to suffice. Nothing is delivered upon. ${ }^{174}$ This is exemplified by the policies, to suspend inspections and contractualise workers, which were adopted by General Ayub Khan, General Zia-ul-Haq and General Parvez Musharraf on an ad hoc basis, and by provincial governments that created trade policies or issued orders that suspended factory inspections by their respective labour departments. ${ }^{175}$ During his time in office, former Prime Minister Zulfiqar Ali Bhutto also had his share of stand-offs with the labour movement when they got in the way of his economic aspirations for the country, despite the fact that he ran for election on a pro-labour mandate. $^{176}$

Slowly but surely, state suppression and direct and indirect violence wore down the labour movement in Pakistan. ${ }^{177}$ At present, only one percent of the workforce is unionised. This makes workers' resistance to cruel and dehumanising labour practices more difficult, if not virtually impossible in practice. As a result, workplaces are increasingly unsafe and employers can get away with banning and sabotaging bona fide labour unions, and even setting up their own pocket unions to disrupt the work of bona fide unions. ${ }^{178}$ Countries that once boasted strong labour movements now find themselves speeding towards a "global race to the bottom." ${ }^{179} \mathrm{OSH}$ is absent or

\footnotetext{
${ }^{174}$ For example, the Sindh Occupational Safety and Health Act 2017 promises inspections, trainings, curriculums, and coordination with the Sindh Building Control Authority (SBCA) and expands the scope of the OSH infrastructure all the way to self-employed persons. Yet, it is not based on any quantitative research and it provides no mechanism through which the Sindh Labour Department could actually achieve even half of these aspirations. For example, if the law had included an incremental implementation scheme where $\mathrm{X}, \mathrm{Y}$ or $\mathrm{Z}$ had to be implemented within the next five years, then perhaps A, B and C could have been implemented in the next five years, and so forth. Alternatively, or additionally, the responsibility for implementing the Sindh Occupational Safety and Health Act could have been shared with the local governments' union councils, or inspectors from the SBCA and Sindh Labour Department could have been pooled to ensure quicker or more thorough inspections. However, this law was not designed to be enforced, only to imitate the ideal.

${ }^{175}$ “The policy for labor inspections changed in 2003 after a military coup by Gen. Pervez Musharraf [...] Punjab, the country's largest province, banned labor inspections through the Punjab Industry Policy in 2003 with the objective of 'developing an industry and business-friendly environment to attract fresh investment'." Ijaz S, No Room to Bargain. Human Rights Watch, 23 January 2019, www.hrw.org/report/2019/01/23/no-room-bargain/unfair-and-abusive-laborpractices-pakistan (last accessed 12 August 2020).

${ }^{176}$ Ali (2005).

${ }^{177}$ See Eleazar and Khan, White-lipped, Blue-collared and Invisible. Himal Magazine, 31 January 2018, www.himalmag.com/pakistan-privatisation-labour-unions-history/ (last accessed 12 May 2020).

${ }^{178}$ See Sumbul and Ali, Labour Movement in Pakistan. Alternatives International, 1 June 2017, www.alterinter.org/?Labour-Movement-in-Pakistan (last accessed 12 May 2020).

${ }^{179}$ Orleck (2018), p. 126; "Now, there are some 8,500 plus registered trade unions with a combined membership of not more than 500,000 workers. And these unions exist in not more than 1,500 enterprises. On an average, there are more than four or five unions in each plant." See Sumbul and Ali, Labour Movement in Pakistan. Alternatives International, 1 June 2017, www.alterinter.org/? Labour-Movement-in-Pakistan (last accessed 12 May 2020).
} 
dysfunctional because vastly profitable foreign companies from core countries want cheap production and need or want peripheral countries to provide this at the cost of their labour and safety regimes. This is made possible by a combination of international pressure, enticement and directions from international financial institutions, such as the IMF, to open peripheral economies to international trade.

Interestingly, the core countries, just as colonisers did before them or as they did as colonisers, continue to peddle the narrative that these disruptions actually benefit peripheral countries. For example, in the mid-1990s, as part of its campaign titled the "girl effect," the biggest shoe company in the world, Nike, engaged the famous feminist historian Jill Ker Conway to tour college campuses and sell the idea that sweatshop work, in homes or in factories such as the Ali Enterprises factory, was liberating for women. ${ }^{180}$

\section{Incarcerated on the Outside: The Contractual Worker- Legality Versus Reality}

The workers at the Ali Enterprises factory worked for an average of 11 to $14 \mathrm{~h}$ a day, had no access to a healthcare plan, and, not even a single worker had an appointment letter that could establish a clear employment relationship with Ali Enterprises. ${ }^{181}$ The majority of the Pakistani labour force, particularly in the garment and textile industry, is employed as contractual labour through third-party subcontractors. ${ }^{182}$ As a matter of practice, relying on the indirect nature of the workers' employment, employers deny them basic rights and entitlements, such as proof of employment, safe workplaces, compensation in case of injury, fatality or disease, social security, healthcare, and even the timely payment of minimum wages. ${ }^{183}$ Under the system of subcontracting, employers such as Ali Enterprises pay a lump sum to a subcontractor, who then hires and fires workers as it pleases them. ${ }^{184}$ This is a dehumanising practice. Workers should be hired as formal or permanent employees who would have to be given their rights such as negotiating power and employment benefits.

\footnotetext{
${ }^{180}$ Orleck (2018), pp. 130-133.

${ }^{181}$ Farhat, Baldia Factory Fire Incident 4 years of successful campaign for justice. December 2016, www.piler.org.pk/wp-content/uploads/2017/02/Brief_Baldia_Factory_Fire-_Incident.pdf (last accessed 12 August 2020).

${ }^{182}$ Ijaz S, No Room to Bargain. Human Rights Watch, 23 January 2019, www.hrw.org/report/2019/ 01/23/no-room-bargain/unfair-and-abusive-labor-practices-pakistan (last accessed 12 August 2020).

${ }^{183}$ Ijaz S, No Room to Bargain. Human Rights Watch, 23 January 2019, www.hrw.org/report/2019/ 01/23/no-room-bargain/unfair-and-abusive-labor-practices-pakistan (last accessed 12 August 2020).

${ }^{184}$ Ijaz S, No Room to Bargain. Human Rights Watch, 23 January 2019, www.hrw.org/report/2019/ 01/23/no-room-bargain/unfair-and-abusive-labor-practices-pakistan (last accessed 12 August 2020).
} 
Instead, the workers' labour is sieved from their humanity, and it is bought and sold from the subcontractor as if it were a textile sold by a retailer.

The trend towards hiring contractual labour is global, but it is particularly dominant in peripheral states. It is accompanied by trade liberalisation, absentee labour protections, and dishevelled labour movements. ${ }^{185}$ This sterilised and zombified workforce is a manifestation of homo sacer. The workers whose employers "evade legal responsibility for meeting minimum wage, maximum hours, and safety standards by classifying them as 'temporary' or as 'contract' employees provided by third party labour suppliers" have no job security, seniority, or benefits. ${ }^{186}$ I agree with Annelise Orleck; these workers are truly the "victims of what should be considered a vast criminal conspiracy." 187 Although there are nuances that differentiate contract workers from subcontracted workers and casual workers, ${ }^{188}$ for the purposes of this discussion, I will collectively refer to those who are denied basic workplace safety and employment benefits, and thus reside in a limbo between worker and non-worker status, as the "precariat." 189

It is a widely held belief that if a worker is a precariat, then they are not entitled to labour protections, ${ }^{190}$ but, legally speaking, this is a mistake. In legal terms, there are various laws and a plethora of legal precedent from case law which confirm that the precariat must be as protected as any other worker in Pakistan, particularly in terms of workplace safety, and almost as protected with respect to their terms of employment. This is even obvious from the definitions of a "worker" provided in some of the key labour laws of Pakistan, as applicable to the province of Sindh. First, the Sindh Factories Act of 2015 stipulates that "no worker shall be employed through an agency or contractor or sub-contractor or middleman or agent, to perform production related work." ${ }^{191}$ That is, first, the Sindh Factories Act 2015 forbids the hiring of workers through contractors or subcontractors. That is, it forbids the use of precariat labour. ${ }^{192}$ The Sindh Workers' Welfare Fund Act of 2014 states that workers include anyone employed "either directly or through a contractor whether the terms of employment be expressed or implied." 193 The Sindh Employees Social Security Institution Act of 2016 states that an "employee" means any person "employed,

\footnotetext{
${ }^{185}$ Orleck (2018).

${ }^{186}$ Orleck (2018), p. 67.

${ }^{187}$ Orleck (2018), p. 100.

${ }^{188}$ Section 2 of the Sindh Terms of Employment (Standing Orders) Act, 2015 (Sindh Act No. XI of 2016).

${ }^{189}$ Orleck (2018), p. 100.

${ }^{190}$ Orleck (2018), p. 67; Ijaz S, No Room to Bargain. Human Rights Watch, 23 January 2019, www. hrw.org/report/2019/01/23/no-room-bargain/unfair-and-abusive-labor-practices-pakistan (last accessed 12 August 2020).

${ }^{191}$ Section 2(n) of the Sindh Factories Act 2015.

${ }^{192}$ Section 2(n) of the Sindh Factories Act 2015.

${ }^{193}$ Section 2(m) of the Sindh Workers Welfare Fund Act (2014).
} 
whether directly or through any other person for wages or otherwise." 194 Even the 1923 Workmen's Compensation Act states that a "workman" is "other than a person whose employment is of a casual nature and who is employed otherwise than for the purposes of the employer's trade or business."195 This thus includes contractual workers but omits casual employees from the ambit of workmen entitled to compensation, and has effectively read down with respect to this omission of casual workers ${ }^{196}$ on the principle of consistency. ${ }^{197}$

According to the Sindh Terms of Employment (Standing Orders) Act 2015, a "“permanent worker" is a worker who has been engaged on work of permanent nature likely to last more than nine months and who has satisfactorily completed a probationary period of three months" 198 and legal precedent clearly states that regardless of the garb under which workers have been hired, "it is essential to look to the nature of work against which he has been employed" in order to determine if they are to be deemed to have rights as permanent workers. That is, if the job is anticipated to last nine months, then the worker employed for it shall be deemed a permanent worker who cannot be arbitrarily removed from service. ${ }^{199}$ The terms of employment of workers cannot legally be manipulated to deny the protections to which they would be entitled as permanent workers. ${ }^{200}$ If the nature of a job is that of permanent work, then a worker is to be deemed a permanent employee. ${ }^{201}$

So, as the law strictly stands, the precariat is legally protected. Even generally, although previously the courts denied coverage of labour laws to contractual workers, ${ }^{202}$ in recent years they have held that labour laws $d o$ apply to contract workers - on the principle of consistency. ${ }^{203}$ Nevertheless, these developments in the ivory towers of law and law-making are distant from the lived reality of the precariat, who is in fact, not protected from even the worst form of abuse and

\footnotetext{
${ }^{194}$ Section 2(9) of the Sindh Employees Social Security Institution Act 2016.

${ }^{195}$ Section 2(n) of the Workmen's Compensation Act 1923.

${ }^{196}$ The doctrine of reading down provides judges with an interpretive tool for narrowing or widening the scope of a statute in order to make the statute accord with constitutional principles. See Hume (2014), p. 620.

${ }^{197}$ AIR 1946 All. 473; P L D 1964 Kar. 406; 1970 P L C 747; P L D 1971 Dacca 200: "In view of the above, it is apparent that a labourer who is paid his wages on a daily or weekly basis can also be termed as a workman within the meaning of clause (n) of section 2(1) of the P W. C. Act, 1923." ${ }^{198}$ Clause 1(b) of the Schedule to the Sindh Terms of Employment (Standing Orders) Act, 2015. ${ }^{199} 2001$ PLC Supreme Court 583 at Para 4.

${ }^{200} 2002$ PLC Supreme Court 67 at Para 8 \& 11.

${ }^{201} 2018$ PLC Supreme Court 182 at Para 4; See also 2020 PLC Sindh High Court 19 at Para 4, 17 (Upheld decision of the lower court to reinstate workers not formally hired as permanent workers with back benefits) and 1989 SCMR 888 at Para 4 \& 6(9) (regarding payment of social security being the responsibility of principal employer even if the subcontractor failed to make social security contributions).

${ }^{202}$ See 1993 S C M R 672; P L D 2000 Supreme Court 207.

${ }^{203}$ See 2011 PLD Supreme Court 37; 2012 PLC 232; 2018 PLC (CS) 228; 2016 P L C (C.S) 179; 2000 PLD Supreme Court 207.
} 
endangerment, as has been exemplified by the AE factory fire. Since there is a large surplus of labour, ${ }^{204}$ workers are replaceable and, as shown above, the law is unenforced as it is. Thus, the employers are neither threatened by a dearth of workers nor by punishment under the law. Using the fact that workers are hired through contractors, employers excuse themselves from responsibility by saying that the workers are not directly employed by them and thus manage to deny the workers their rights and entitlements. The precariat is confined on the outside of law.

Despite these legal protections, the precariat continues to be endangered. As Agamben asserts, the state of exception "is a hybrid of law and fact in which the two terms have become indistinguishable."205 In case of injury, fatality or disease, the foreign companies whose product the precariat is making will not admit any liability and will hold the factory accountable, while the factory will hold the subcontractor accountable, from whom the precariat will often not even have proof of employment. ${ }^{206}$ The precariat thus continues to be incarcerated in limbo, unprotected. The homo sacer - in this case, the incarcerated precariat-is "devoid of any representable identity" and "is absolutely irrelevant to the State." 207 Here, the precariat's factual existence, their work and their legal non-existence, without proof of employment or a clear employment relationship, are constantly interchangeable; "a continent may integrate on liberal-democratic agenda, still there would be no place for those who remain outside the law." 208

\subsection{Use and Abuse: Legal Protections Versus Contracts}

Peripheral states are, of course, willing participants in the dehumanisation of their workers, who are forced into unsafe and cruel working conditions and suffer disasters like the Ali Enterprises factory fire. The peripheral state is haunted and animated by methods of the core. ${ }^{209}$ The methodology of instrumentalisation of entire populations (workers in this case), as if they were a mere tool for statecraft, is perhaps equally rooted in colonial history and in the contemporary global political economy. Mass contractualisation of the workforce and the consequent denial of workers' rights and entitlements through the convoluted use of legal contracts, such as the one between the principal employer and the subcontractor, betrays an alarming truth - the law "only rules over what it is capable of interiorizing" and these internal

\footnotetext{
${ }^{204}$ Labour Force Survey (2017-18), Pakistan Bureau of Statistics.

${ }^{205}$ Agamben (1998), p. 170.

${ }^{206}$ As KiK initially did, for example.

${ }^{207}$ Agamben, Coming Community, pp. 86-87 quoted in Nashef (2017).

${ }^{208}$ Samaddar (2010), p. xxvi.

${ }^{209}$ Mbembe (2003), p. 25.
} 
colonies of those confined on the outside of law are governed by the state of exception. ${ }^{210}$ Here perhaps the postcolonial state is mirroring the character of its antecedent - the colony which "were 'frontiers' in which 'savages' resided.",211 Hence, the precariat is interiorised through oral or informal contracts and wages but exteriorised from the protections of labour law under which, for example, safe working conditions could be demanded. The precariat is banished to the state of exception where labour law practically does not apply. ${ }^{212}$

Labour law recognises the power differential between workers and employers. Accordingly, it grants concrete protections like guaranteed compensation in cases of workplace fatality, injury, or disease. On the other hand, contract law assumes the equality of contracting parties. Hence, the contractualisation of workers has pre-emptively thrown many workers outside the basic protections of labour law; the fact that contractual norms govern their day-to-day employment has meant that increasingly large numbers of workers are in muddy waters. Because workers are unprotected and the free supply of labour makes them readily replaceable, workers are more easily coerced into working in unsafe conditions. Contractualisation has thrown workers into uncertainties and made them excessively vulnerable to exploitation. $^{213}$

\footnotetext{
${ }^{210}$ Mbembe (2003), p. 24.

${ }^{211}$ Deleuze and Guattari (1980), p. 445.

${ }^{212}$ Mbembe (2003), p. 24.

${ }^{213}$ The Ali Enterprises Factory was producing garments for the German company KiK. As it presently stands, hiring the services of a Pakistani worker is almost 24 times cheaper for a European company than hiring a European worker. For example, as of May 2020, the minimum wage payable to a Pakistani worker was approximately 17,500 Pakistani rupees per month. According to reports, the average textile worker works $10 \mathrm{~h}$ per day, six days per week. The German minimum wage for 2020 is 9.75 euros per hour, which is 1703 Pakistani rupees. If a worker in Germany works a 10-h day, even if they are not paid an overtime rate, they would be making 17,030 Rupees for $10 \mathrm{~h}$ of work. In one day, a worker in Germany is likely to make as much money as a worker in Pakistan makes in a month. Unlike the Pakistani worker, the German worker is also likely to have access to health insurance, workplace safety, adequate housing, sickness and unemployment benefits, free higher education, and (state run/price regulated) public transport. Moreover, the average household size in Pakistan is 6.8 persons, while the average household size in Germany is 2.1 persons. Therefore, the Pakistani worker has more dependents, including elderly family members (whom the state does not provide health or pension) and children (for whom the state does not provide healthcare or primary education and need to be educated on the worker's dime. So, it is even more important for the worker in Pakistan to have safe work and to stay healthy and alive even if just to sustain their dependents. However, do note that this comparison is not adjusted for the fact that the cost of living may be higher in Germany but it is believed that despite that, it is fairly straightforward to imagine that the workers in Pakistan are vastly disadvantaged compared to the ones in Germany. Additionally, production of goods for foreign markets also corrodes the limited pool of basic resources available to those in peripheral economies. For example, the production of one T-shirt takes approximately 27001 of water while one pair of jeans consumes approximately 99821 of water (Orleck 2018).
} 


\subsection{The Bangladesh Accord on Fire and Building Safety}

In the face of apathetic government agencies, ineffective OSH infrastructure, and convoluted myths and realities regarding who is liable when workers suffer death, injury, or disease, workers have begun to seek means to hold foreign companies directly accountable. They are "no longer willing to let them hide behind their complex and fragmented global value chains." 14 Kalpona Akhter, the founder of the Bangladesh Centre for Worker Solidarity, puts it simply: "There is a worker and a clothing company. I don't want to know who is in between.",215

In 2013, following in the wake of the Raza Plaza collapse, the Tazreen Fashions factory fire, and other disasters, the workers of Bangladesh, organising through trade unions and in cooperation with NGOs, international activists, and OSH experts drafted the Bangladesh Accord on Fire and Building Safety (Bangladesh Accord). ${ }^{216}$ However, in mid-2018, the Bangladesh Accord was sued by a Bangladeshi factory owner, who had been removed from the list of approved suppliers due to safety breaches. In June 2018, the Bangladeshi Minister for Commerce stated that the government-led body, which in truth "reports a woefully low $29 \%$ completion rate for mandatory safety renovations at factories the government is ostensibly regulating," 217 was somehow capable of overseeing workers' safety. As such, he announced that the Bangladesh Accord was no longer needed, saying "factories are now safe and worker-friendly." 218 Thus, the Bangladesh Accord now stands on precarious ground, much like the precariat, whose precarious employment and working conditions it aims to protect.

The key difference between labour law and most contractually governed frameworks is that the latter does not recognize power differential between workers and employers. Although the Bangladesh Accord is something like a traditional bargaining agreement between labour representatives and employers, its treatment by actors like the local manufacturers and the Bangladeshi government has resembled that of a (multi-stakeholder) contract. This is because there is no direct liability

\footnotetext{
${ }^{214}$ Orleck (2018), p. 139.

${ }^{215}$ Orleck (2018), p. 139.

${ }^{216}$ With the help of global partners, it was even able to take major international companies to the Permanent Court of Arbitration in Geneva and get large compensation settlements for workers. See: Bangladesh Accord arbitration cases - resulting in millions-of-dollars in settlements - officially closed, UNI Global, 18 July 2018, www.uniglobalunion.org/news/bangladesh-accord-arbitrationcases-resulting-millions-dollars-settlements-officially-closed (last accessed 24 May 2020); For a detailed discussion, see Ben Vanpeperstraete's chapter in this book.

${ }^{217}$ See Christie, Response to Today's High Court Hearing on Bangladesh Accord. Clean Clothes Campaign, 29 November 2018, www.cleanclothes.org/news/2018/11/29/response-to-todays-highcourt-hearing-on-the-bangladesh-accord (last accessed 24 May 2020).

${ }^{218}$ See Davoise, On borrowed time: five years after the Rana Plaza disaster, the Bangladesh Accord faces Court ordered closure. INTLAWGRRLS, 28 November 2018, www.ilg2.org/2018/11/28/onborrowed-time-five-years-after-the-rana-plaza-disaster-the-bangladesh-accord-faces-court-orderedclosure/ (last accessed 24 May 2020).
} 
or legal obligation between the labour representatives, their allies and the foreign brands that (have been convinced to) make commitments under the Bangladesh Accord. Unfortunately, under the prevailing paradigm of "imperial international economic policy," and the resultantly fragmented global value chains and independent contracts, labour representatives and allies have had to creatively improvise but this has not protected them from attack. Because the Bangladesh Accord is essentially a contract between foreign companies and trade unions, NGOs, and INGOs, it is vulnerable to interventions from the local manufacturers, government and the courts of Bangladesh. ${ }^{219}$

Supply contracts of foreign companies for manufacturers in peripheral economies are often puffed up with requirements, such as the evidently hollow SA-8000 certification, which had been obtained by both the Ali Enterprises factory in Pakistan (approximately 20 days before the 2012 fire) and by Rana Plaza in Bangladesh (also less than a month before its 2013 collapse). ${ }^{220}$ This ill-intentioned bid at seeking legitimacy without taking responsibility for safety lapses is somewhat similar to, although perhaps worse than, twentieth-century United States. In the early twentieth century, caught in the midst of a movement for workplace safety and facing increased costs for workplace injuries and fatalities, US businesses were also moved to self-regulate in what became known as the Voluntary Safety Movement. Under this movement, the Voluntary Safety Council was established in 1913 and it pushed for safety engineering and better working practices. However, this self-regulation reeked of the same self-interest that British textile interests had shown in British India. Most safety education imparted to workers was premised on the notion that the majority of workplace accidents were due to the workers' negligence. It promoted the notion of "their fault, their liability." The Voluntary Safety Movement also funded various propaganda. For example, in 1911, the year of the Triangle Shirtwaist Factory fire mentioned above (which took 146 lives mostly consisting of young immigrant women) the National Association of Manufacturers reigned in the support of progressive filmmaker James Oppenheim to produce the film The Crime of Carelessness, stressing that workers were the cause of workplace accidents. ${ }^{221}$

\footnotetext{
${ }^{219}$ See Christie, Response to Today's High Court Hearing on Bangladesh Accord. Clean Clothes Campaign, 29 November 2018, www.cleanclothes.org/news/2018/11/29/response-to-todays-highcourt-hearing-on-the-bangladesh-accord (last accessed 24 May 2020).

${ }^{220}$ Theuws et al (2013).

${ }^{221}$ Occupational Health and Safety Administration, Can't take no more. 1980, www.youtube.com/ watch?v=13gzGkQtVzg (last accessed 6 June 2020).
} 


\section{Conclusion}

As we have seen above, the absence or presence of OSH depends on the needs of the global economy more than it does on actual workplace hazards. The history of OSH in Pakistan is one of regulation and dis-operationalisation, as per the needs of the powers that be. The OSH infrastructure in Pakistan is not meant to make the workplace safer, instead it is an empty signifier, an ornamental imitation of core countries' OSH infrastructures. These laws are utopian insofar as they do not reflect the economic or regulatory capacity of Pakistan, and dystopian in that completely disregarding them and endangering workers is allowed, if not encouraged, in practice. OSH infrastructures, whether deployed by peripheral states or at the behest of core countries, are a legal fiction at best-to be progressively realised at an unknown date in the unforeseeable future. A useful way to mitigate the existing problems, whilst recognizing the constraints of the global politico-economic order, may be to indigenise and democratise the OSH infrastructure through actual and substantive worker participation, legal liability for foreign companies (that outsource their production), and the activation of transnational solidarity among workers. ${ }^{222}$

On regulators' end, instead of blindly copying the OSH infrastructures of core countries, we would need to rethink OSH in terms of local context. As a first step towards worker safety, the OSH mandate needs to be stratified and staggered such that the higher priority safety requirements are separated in the interim and pursued with the full force of the existing institutional capacity, so that the most urgent needs of workplace safety can be addressed first and the rest can follow. The remaining aspects of workplace safety can be progressively mainstreamed as institutional capacities are improved and increased. Less expensive alternatives or communitybased mechanisms of enforcement (such as Local Governments and Union Councils being made responsible for workplace inspections based on checklists prepared by technical experts) could also potentially be explored. Second, it is important for regulatory authorities to reject self-regulatory certifications that bolster supply contracts, such as the SA-8000. If worker safety is to be improved, labour law must be reinstated and the trend towards contractualization of labour law must be stopped. Third, regulator accountability mechanisms need to be established as well. Government regulators need to be capacitated, empowered, and held accountable. Fourth, this accountability would perhaps only be possible if the regulator was directly accountable to the workers, through participatory and democratic mechanisms. Eventually, the seats at the table need to be in proportion to the number of lives at stake, not only according to the profits at stake. To give each group one seat each would be to perpetuate the dehumanisation of the precariat by nakedly equating the value of money (of local and global companies), power (of regulators), and human life (of workers and families). Workers, foreign companies, local manufacturers and government agencies may need to sit on one representative table. The OSH council that is envisaged in the OSH Act of 2017, does have seats for workers'

${ }^{222}$ Orleck (2018). 
representatives, and elected OSH representatives; this is a tiny step in the right direction. Much would have to follow for these carceral patterns and cruel work conditions to be disrupted-in Pakistan and across the globe.

\section{References}

Afzal M (2007) The impact of globalisation on economic growth of Pakistan. Pak Dev Rev 46 (4):723-734

Agamben G (1998) Homo sacer: sovereign power and bare life. Stanford University Press, Stanford Ahmed F (1974) Pakistan forum: partners in underdevelopment: Pakistan and the US. MERIP Rep 26:23-27

Ali K (2005) The strength of the street meets the strength of the state: the 1972 labor struggle in Karachi. Int J Middle East Stud 37(1):83-107

Brown D, Brown C, Desposato S (2007) Promoting and preventing political change through internationally funded NGO activity. Latin Am Res Rev 42(1):126-138

Child FC, Kaneda H (1975) Links to the green revolution: a study of small-scale, agriculturally related industry in the Pakistan Punjab. Econ Dev Cult Chang 23(2):249-275

Chossudovsky M (1979) Human rights, health, and capital accumulation in the Third World. Int J Health Serv 9(1):61-75

Deleuze G, Guattari F (1980) A thousand plateaus: capitalism and schizophernia. Continuum, New York

Elshtain J (1991) Sovereign god, sovereign state, sovereign self. Notre Dame Law Rev 66:1355-1378

Feenstra R (1998) Integration of trade and disintegration of production in the global economy. J Econ Perspect 12(4):31-50

Gayer L (2019) Putting out the Baldia factory fire: how the trial of Karachi's industrial capitalism did not happen. In: Harriss-White B, Michelutti L (eds) The Wild East: criminal political economies in South Asia. UCL Press, London, pp 288-321

Gilbert M (1982) Lord Lansdowne and the Indian Factory Act of 1891: a study in Indian economic nationalism and proconsular power. J Dev Areas 16(3):357-372

Gramsci A (1971) Selections from the prison notebooks. In: Hoare Q, Nowell Smith G (eds) London

Hobson C (2009) The limits of liberal-democracy promotion. Altern: Global Local Polit 34 (4):383-405

Hume D (2014) The rule of law in reading down: good law for the 'bad man'. Melbourne Law Review, Melbourne

Kamat S (2004) The privatization of public interest: theorizing NGO discourse in a neoliberal era. Rev Int Polit Econ 11(1):155-176

Klimnik K (1988) German occupational safety and health regulation from an American perspective. Penn State Int Law Rev 6(2):143-235

Louai E (2012) Retracing the concept of the subaltern from Gramsci to Spivak: historical developments and new applications. Afr J Hist Cult 4(1):4-8

Manby B (2009) Struggles for citizenship in Africa. Zed Books, London

Mbembe A (2003) Necropolitics. Public Cult 1(15):11-40

Mende J (2020) Business authority in global governance: beyond public and private. WZB Berlin Social Science Center Discussion Paper 4:2020-2103

Meyer T (2018) Free trade, fair trade, and selective enforcement. Columbia Law Rev 118 (2):491-566

Nashef H (2017) Homo sacer dwells in Saramago's land of exception: blindness and the cave. Angelaki: J Theor Humanit 22(4):147 
Orleck A (2018) We are all fast food workers now: the global uprising against poverty wages. Beacon Press, Boston

Otto D (1996) Subalternity and international law: the problems of global community and the incommensurability of difference. Soc Leg Stud 5(3):337

Powell B (2014) Meet the old sweatshops: same as the new. Indep Rev 19(1):109-122

Puplampu B, Quartey S (2012) Key issues on occupational health and safety practices in Ghana: a review. Int J Bus Soc Sci 3(19):151-156

Samaddar R (2010) Emergence of political subject. SAGE, London

Sheth D (1995) Democracy and globalization in India: Post-Cold War discourse. Ann Am Acad Polit Soc Sci 540:24-39

Spindler M (2013) World-systems analysis. In: International relations: a self-study guide to theory. Verlag Barbara Budrich, Toronto, p 177

Spivak G (2010) Can the subaltern speak?: Reflections on the history of an idea. In: Morris R (ed)

Theuws M et al (2013) Analysis of recent factory fires in Pakistan and Bangladesh: a call to protect and respect garment workers' lives. In: Stichting Onderzoek Multinationale Onderneminge (eds) Clean clothes campaign. Amsterdam

Palvasha Shahab was the joint executive director of the Rasheed Razvi Centre for Constitutional and Human Rights, and the Legal Aid Foundation for Victims of Rape and Sexual Assault through September 2020. She now works a consultant for RCCHR, LAFRSA, the Legal Aid Society and the Pakistan Institute for Labour Education and Research. She is on the Law Committee of the Sindh Commission of the Status on Women and advises on upcoming legislation. She is also an advisor to a transnational collaborative project on oral histories and social interventions titled "Karachi Beach Radio." She has also taught undergraduate courses on peace movements and international human rights law at SZABIST, Karachi. Shahab further curates and moderates important public discussions on national platforms such as the Adab Fest and The Second Floor. She holds a Master of Laws from Columbia Law School, New York, US, where she was also a Human Rights Fellow at the Human Rights Institute in 2017-18.

Open Access This chapter is licensed under the terms of the Creative Commons Attribution 4.0 International License (http://creativecommons.org/licenses/by/4.0/), which permits use, sharing, adaptation, distribution and reproduction in any medium or format, as long as you give appropriate credit to the original author(s) and the source, provide a link to the Creative Commons license and indicate if changes were made.

The images or other third party material in this chapter are included in the chapter's Creative Commons license, unless indicated otherwise in a credit line to the material. If material is not included in the chapter's Creative Commons license and your intended use is not permitted by statutory regulation or exceeds the permitted use, you will need to obtain permission directly from the copyright holder.

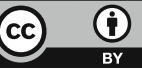

